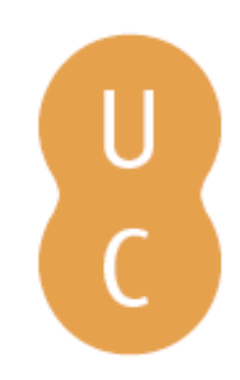

\title{
nombalina
}

\section{Escrever tem arte e tem segredos... Era bom que trocássemos umas ideias sobre 0 assunto}

\author{
Autor(es): $\quad$ Silva, Maria de Fátima \\ Publicado por: Imprensa da Universidade de Coimbra \\ URL \\ persistente: URI:http://hdl.handle.net/10316.2/37025 \\ DOI: $\quad$ DOI:http://dx.doi.org/10.14195/978-989-26-0548-7_5 \\ Accessed : $\quad$ 26-Apr-2023 12:46:48
}

A navegação consulta e descarregamento dos títulos inseridos nas Bibliotecas Digitais UC Digitalis, UC Pombalina e UC Impactum, pressupõem a aceitação plena e sem reservas dos Termos e Condições de Uso destas Bibliotecas Digitais, disponíveis em https://digitalis.uc.pt/pt-pt/termos.

Conforme exposto nos referidos Termos e Condições de Uso, o descarregamento de títulos de acesso restrito requer uma licença válida de autorização devendo o utilizador aceder ao(s) documento(s) a partir de um endereço de IP da instituição detentora da supramencionada licença.

Ao utilizador é apenas permitido o descarregamento para uso pessoal, pelo que o emprego do(s) título(s) descarregado(s) para outro fim, designadamente comercial, carece de autorização do respetivo autor ou editor da obra.

Na medida em que todas as obras da UC Digitalis se encontram protegidas pelo Código do Direito de Autor e Direitos Conexos e demais legislação aplicável, toda a cópia, parcial ou total, deste documento, nos casos em que é legalmente admitida, deverá conter ou fazer-se acompanhar por este aviso.

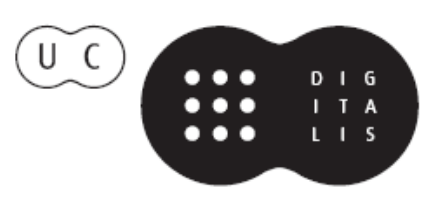


do Tempo e da História

- Mário de Carvalho e a reflexáo metaficcional sobre o futuro do romance - Sátiva e o cepticismo: configuração de personagens em Mário de Carvalho - Escrever tem arte e tem segredos... Era bom que trocássemos umas ideias sobre o assunto - O processo criativo em Era bom que trocássemos umas ideias sobre o assunto - Intertextualidade e metaficção em Fantasia para dois Coronéis e uma Piscina, de Mário de Carvalho - Trimalquiāo, os coronéis e a piscina: retrato impiedoso de um pais em crise $\bullet A$ Paixão do Conde de Fróis: paródia e subversão • "Como dizia o outro": a presença dos Clássicos em Mário de Carvalho - Cultura Clássica em Um

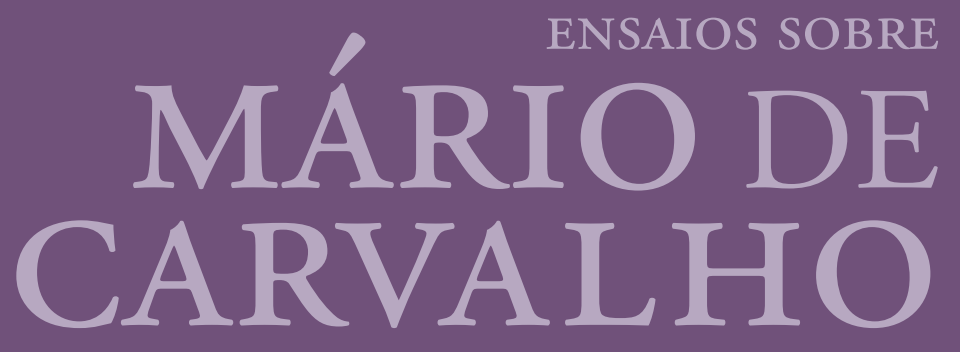

Maria de Fátima Silva Tereza Virgínia Ribeiro Barbosa COORD. IMPRENSA DA UNIVERSIDADE DE COIMBRA COIMBRA UNIVERSITY PRESS

elemento mouro como simbolo de alteridade $e$ barbárie em Um deus passeando pela brisa da 


\title{
Escrever tem arte e tem segredos... Era bom que trocássemos umas ideias sobre o assunto
}

\author{
Maria de Fátima Silva \\ Universidade de Coimbra
}


(Página deixada propositadamente em branco) 
A posição da literatura é muito ambígua. É ela a rainha da cultura, a grande dama, a grande experiência, revelação e tremor; mas com uma facilidade pasmosa cai destes cúmulos para se converter em passatempo, em hieróglifo, em exibição de destreza verbal.

Zagajewski, A., En la belleza ajena, trad. esp. de A. E. Diaz-Pintado Hilario, $97^{1}$.

Era bom se trocássemos umas ideias sobre o assunto é não apenas uma narrativa bem sucedida de quadros e personagens da realidade portuguesa contemporânea, como um 'manual' de arte de escrever. 'Manual' entenda-se, construído sobre um diálogo frequente entre o narrador e as suas personagens, de um lado, mas principalmente entre M. Carvalho e o seu leitor ${ }^{3}$. Em apontamentos breves, dispersos por momentos múltiplos, o autor medita e comunica preocupaçóes de concepçáo e estética, relacionadas com a estrutura da narrativa, o desenho das personagens e a eficácia da linguagem, a que ele mesmo deita mão no seu romance ${ }^{4}$. Atento às normas - algumas delas bebidas na tradição greco-latina, outras arquitectadas e estabelecidas ao longo de séculos de criação e de crítica literária - e à estética da transgressão que a partir delas se constrói, M. Carvalho é o prosador atento, profissional, além de um extraordinário criador em

1 2003, Valencia, Pre-Textos.

2 52003, Lisboa, Caminho.

3 M. Carvalho domina uma técnica eficaz do que Reis, C., Macário Lopes, A. C. (72007), Dicionário de narratologia. Coimbra, Almedina: 207-210 designam por "intrusão do narrador", com índole e motivação diversa, mas com o objectivo permanente de projectar no enunciado narrativo a subjectividade do narrador. O que, no aspecto que nos propomos abordar, diz respeito ao próprio processo narratológico.

4 Estamos perante o que Genette, G. (1972), Figures III. Paris, Le Seuil: 244 denomina como metalepse, como o processo de intervenção do narrador no curso do texto, com objectivos que são neste caso, antes de mais, lúdicos, mas que não deixam de ser também doutrinários. Na mesma linha, é ainda de recordar Malina D. (2002), Breaking the frame: metalepsis and the construction of the subject. Columbus, Ohio State UP: 9: "A metalepse pode não se ficar por um mero efeito retórico que nos afecte - que nos indique novas formas de ler e de pensar o nosso próprio mundo; pode ter também um efeito transformativo, permitindo-nos, pontualmente, experimentar novas formas de ser, na medida em que romances metalépticos constroem, de alguma forma, a nossa subjectividade”. Sobre metalepse, vide ainda Reis, Macário Lopes ${ }^{7} 2007$ : 232-233. 
língua portuguesa. Como bem afirma Marta T. Anacleto5, ainda que num contexto diferente, mas com igual propriedade para o caso que avaliamos: "Por não poder submeter-se a uma tipologia rigorosa do romance, refugia-se num modelo de escrita que remete, constantemente, através da paródia e da autocontemplação irónica, ao âmbito próprio de uma semântica da escrita". Assim se abre espaço a que o romance se interrogue sobre si mesmo.

Mas a par da própria escrita, o leitor atento há-de reparar como, neste romance, pela mão das personagens, outras escritas se esboçam, em tonalidades contrastantes. Há quem escreva e acumule peças de teatro, o Jorge Matos, o antigo professor de Francês, em fase de acumular ex-vivências: ex-vítima da PIDE, ex-marido de uma médica, ex-revolucionário, ex-jornalista, ex-professor (47), mas, em continuidade, autor de peças teatrais. Há a prosa jornalística que nos chega, nas suas diversas concepçóes e tonalidades, sobretudo por obra da Eduarda Galvão. E há, mais esparsos, laivos de outros discursos - académico, burocrático, publicitário -, no que é, no seu conjunto, um puzzle bem sucedido de cambiantes no uso da língua. É sobre esta polissemia do texto que nos propomos tecer algumas consideraçôes.

\section{Estratégias de construção da narrativa}

Manda a natureza das coisas que seja o prólogo, e o uso que permite, a primeira ferramenta a considerar na arquitectura de um romance, ou de outra qualquer narrativa. E é também já a partir deste momento inicial que Era bom se afirma crítico de si mesmo e capaz de rejeitar, conscientemente, convençóes instituídas para enveredar por uma opção divergente. Ordem e estilo denunciam, pela transgressão, todo o seu potencial.

Desde sempre que o prólogo, a palavra com que o grego designou a abertura de uma narrativa - ou sobretudo de uma peça teatral - (pró-logos, 'o que antecede a história ou narração'), teve, por função essencial, informar, antecipar ideias, motivos, linhas de acção, orientar o leitor ou espectador para uma expectativa. Ao propósito, juntou-se o sentido de eficácia, a dosagem do conteúdo, o ritmo das informaçóes, o impacto emotivo

5 1996, "(Sub)versions du "cliché" romanesque au XvirI siècle: le "roman bourgeois" de Furetière”, Confluências 14: 99. 
de que poderia ser capaz, para cumprir plenamente o seu papel $^{6}$. É desses pressupostos que M. Carvalho dá conta, à página 18:

E porque já vamos na página dezoito, em atraso sobre o momento em que os teóricos da escrita criativa obrigam ao início da acção, vejo-me obrigado a deixar para depois estas desinteressantes e algo eruditas consideraçóes sobre cores e arquitecturas, para passar de chofre ao movimento, ao enredo. Na página três já deveria haver alguém surpreendido, amado ou morto.

Uma abertura demasiado longa, expositiva, erudita, corre o risco de entediar o leitor - ou, sendo o caso, o espectador - e desmobilizar atençóes. E convive mal com a componente 'acção', perigosamente adiada. Mas há também o problema da informação, em contrapeso com a sedução que se espera de um texto de abertura. Será a informação o essencial deste exercício delicado que é dar início a uma narrativa? Não, é a preferência evidente do autor de Era bom, que continua:

E enquanto me apresso, vou protestando que houve um escritor que demorou trinta magníficas páginas a acordar de um sono e outro que gastou muitas mais a tentar demonstrar, fraudulenta mas genialmente, que a baleia é um peixe.

De resto, o factor 'surpresa' é imprescindível num relato atractivo e impóe, entre prólogo e intriga, um equilíbrio bem medido. Que algo sobre, de imprevisto, para além daquilo que um prólogo obriga a prever.

Uma quebra no romance, a separar uma primeira de uma segunda parte, reclama um novo prólogo e, mais uma vez, uma reconsideração de eficácia. Apesar de abertura, o prólogo sucede agora a uma quebra da acção, a um intervalo de tempo; e, por isso, se lhe exige atenção não só ao que se segue, mas àquilo que, nesse tempo, aconteceu. Um outro instrumento, o da sinopse, se mostra entáo necessário; em vez de um começo "logo de rijo, e em festa", a reverência à teoria exige a tal sinopse. Teatro e novela voltam a confluir na metodologia de conactar tempos e de assegurar a atenção do destinatário. Cumprida a regra, pode o narrador certificar-se com alívio: "Estamos situados?" (117-119).

6 Sobre a natureza do prólogo, designaçôes alternativas, dimensão e funçôes, vide Reis, Macário Lopes ${ }^{7}$ 2007: 343-344. 
Com o momento da abertura, que o romance Era bom situa in medias res, vem a necessidade do que a narratologia consagrou como analepse e o cinema como flash-back . Se, no momento anterior, M. Carvalho apelava à transgressão, passa agora a argumentar com a convenção literária nos seus ascendentes mais antigos (20-21):

Abra-se aqui uma analepse, que é a figura de estilo mais antiga da literatura, vastamente usada pelo bom do Homero, quando não dormia, e náo sei mesmo se pelo autor do Gilgamesh.

E também a este propósito, M. Anacleto (1996: 108) deixa um apontamento interessante sobre "o recordar da presença contínua de um "texto-palimpsesto" sob uma narrativa autêntica”, um factor de constante fascínio em M. Carvalho. Na tradição das poéticas, reflexóes sobre o sentido e a execução técnica da criação artística, que já desde Aristóteles tendem ao confronto das diversas modalidades de mimesis, literatura e artes visuais (modernamente o cinema) aparecem ligadas pelo mesmo expediente. Arte recente, se comparado com as raízes profundas da expressão literária, o cinema, "deslembrado de Homero ou Camóes" - ou seja, da tradição épica como a primeira criação manipuladora das técnicas de abertura in medias res e do flash-back - julga ter descoberto um recurso, novo e próprio, no que não passava de reabilitaçáo, remoçada, de efeitos conhecidos.

No que pretende afirmar-se como uma escrita própria e autónoma, crítica das opções de outros autores, $\mathrm{M}$. Carvalho não hesita em assumir artificialismos retóricos consagrados e em denunciar, como "estranhas e peculiares tinetas" (21) a sua recusa; com o leitor, estabelece um diálogo de divergência, tanto mais afirmativo da sua liberdade de opção:

Não me ocorre agora nenhum escritor que abomine as analepses, mas deve haver algum. Esse não será, com mágoa minha, leitor deste livro, o que lhe restringe perigosamente o alcance".

E segue-se a tal analepse que, para que se acrescente ao processo o toque irónico, não recua, do ponto narrativo em que se introduz, mais do que

7 Uma simples remodelação do nome para uma mesma técnica; vide Reis, Macário Lopes ${ }^{7} 2007$ : 9, 29-31. Na definição dos autores referidos "por analepse entende-se todo o movimento temporal retrospectivo destinado a relatar eventos anteriores ao presente da acção e mesmo, nalguns casos, anteriores ao seu início". 
escassos "quatro minutos e meio". O factor tempo, associado à analepse, mais do que uma dinâmica narrativa, é neste caso um recurso de efeito caricatural de uma antiga estratégia literária.

Estabelecido o movimento de arranque, o curso da narrativa prossegue sujeito a diversos sobressaltos. Na contracapa, o autor sintetiza os traços nevrálgicos da proposta:

Este livro contém particularidades irritantes para os mais acostumados. Ainda mais para os menos. Tem caricaturas. Humores. Derivaçôes. E alguns anacolutos.

E é exactamente dos anacolutos, de como os manobra M. Carvalho, que faremos uma observação breve. Talvez a velha tradição dramática do deus ex machina seja o exemplo extremo da solução para o anacoluto. Quando tudo parece perdido, quando os acontecimentos, confusos ou incompatíveis, parecem não propiciar um final coerente, um deus virá que, da sua elevada autoridade, terá artes de sanar o problema. Deste efeito o autor do romance não faz também cerimónia em servir-se (59), e não propriamente para selar um desfecho difícil, apenas como arma para justificar um anacoluto. Quando a narrativa, centrada em Joel Strosse, parecia fracturar-se pela intervenção inopinada da Eduarda Galvão, o autor condescende numa suspensáo rápida, para dar, às suas duas personagens, em tempos distintos da narrativa, uma importância similar:

Eduarda tem um destino a cumprir e eu arranjarei maneira de a integrar na história, nem que tenha de fazer sair um deus duma máquina. Por agora traço-a assim, em pinceladas rápidas (...) e vou muito direito à finalidade. Mas lá que a Eduarda faz falta, faz. Depois verão.

Momentos há em que o anacoluto funciona não de ameaça de quebra, eventualmente incómoda, da concentração num episódio ou no desenho de uma personagem. Pelo contrário, pode usar-se como refrigério ou oásis literário, uma espécie de "derivativo de deixar assentar os nervos" (81), para aligeirar o normal curso da narrativa:

Eu sou mais pelas prosas pacatas e defendo-me dos frenesis literários. Hei-de contar o que se vai passando com Eduarda e Jorge, por um lado, e Joel e Cremilde por outro, mas em espairecimento. Agora apetece-me um derivativo de deixar assentar os nervos. Conheceis a Caparica?" 
Mas logo, em outras circunstâncias, a eminência defraudada de um anacoluto pode ser um apelo à coesão da intriga e a justificação da prioridade dada a um episódio relevante; estamos em território de manipulação hábil do processo (98):
Ainda bem que ele não telefonou logo a seguir. Eu lá teria de dar con- ta da diligência e isto ia parecer um romance de fio telefónico. Náo seria má ideia, para outra ocasião, mas, agora, a cadeia telefónica viria introduzir cadências repetitivas, tediosas e impedientes de eu contar o que estou ansioso por ..."

A construção fraccionada da intriga, sujeita a diversos anacolutos, suscita o uso de fórmulas, também ele um processo convencional desde Homero de estabelecer enlaces e fronteiras. Sem se dobrar ao peso da repetição, como era de antiga prática, o autor de Era bom recorre com frequência a frases de encadeamento ou relação entre diferentes tempos ou espaços narrativos:

Já lá iremos. Ora esguardemos como se fôssemos presentes - porque, entretanto, transcorreu a noite e chegou a manhã - a Eduarda Galvão ... (71)

Estas traças previsíveis e banais querem ficar, por enquanto, fora desta história ... (73)

... saiamos rapidamente de Belém, após um olhar reverencioso à Torre, e regressemos a casa do Jorge que já comeu a papa toda, acompanhada por uma banana que é o fruto mais prático de descascar. (74)

Urge agora considerar Joel Strosse que deambula em redondo, na sala, de braços atrás das costas. (113)

Agora reparo que há muito tempo não falo do Joel Strosse propriamente dito ... (135)

Em vez da recorrência a um código de repetição, é a variedade criativa que se usa: a alternância de um português antigo e reconhecível ${ }^{8}$ com o contexto contemporâneo da intriga, o contraste entre o cenário público

8 Fernão Lopes, Crónica de D. João I, cap. CXLIX, Lisboa, Livraria Civilização, I, 309. 
e o doméstico, entre a menção histórica ou cultural e a mais comezinha banalidade. Mas por trás dos diferentes efeitos estilísticos, o objectivo é constante: permitir um anacoluto 'coordenado e consciente'.

De certa forma relacionada com o anacoluto, como quebra no curso directo e regular da narrativa, está a descrição ou écfrase, como um processo marginal, uma interrupçáo descritiva, que $\mathrm{M}$. Carvalho com frequência anuncia. A focagem destes blocos descritivos, com alguma autonomia sobre o fio condutor da narrativa, obedece a conteúdos mais ou menos previsíveis: caracterização sistemática de uma personagem, mas sobretudo descriçóes de espaços e ambientes. Estas eram também já as preferências do romance grego da época helenística?

Da oportunidade de um recurso num determinado momento ou contexto fala o autor de Era bom, a propósito de uma das suas personagens:

Discorrerei agora sobre este desvelo de Florentina Palha, a própria, e matérias afins? Não! Há-de calhar a propósito, quando for ocasião. (28)

A que se associa a consciência do risco de fractura ou incoerência que a écfrase implica:

Entristeceu-se por lhe ocorrerem entretanto pesarosas circunstâncias da sua vida, tão deprimentes que só mais adiante as contarei, para não acrescentar, por agora, disforias à disforia, de que esta secção já vai carregada. (31)

Por isso, um esforço de controle e coordenação entre o contexto e o excurso é cautela nunca excessiva:

Concedamos que Joel tinha razão e recolhamo-nos para alguns tópicos íntimos sobre a decadência desta civilização, mas sem o perder de vista. $(31)^{10}$

9 Estas descriçōes, muito comuns no romance grego antigo, como modelos adoptados nas escolas de retórica, pretendiam demonstrar uma versatilidade enciclopédica. Vide Kirk, D. M. (1960), The digression, its use in prose fiction from the Greek romance through the eighteenth century. Stanford University; Davison, M. (1976), "The thematic use of ekphrasis in the ancient novel", in Erotica antiqua. Acta of the International Conference on the Ancient Novel. Bangor, ICAN; Fowler, D. P. ((1991), "Narrate and describe: the problem of ecphrasis", JRS 81: 25-35.

10 Este é o exemplo da descrição que Hamon, P. (1976), “O que é a descrição?”, in Seixo, M. A. (ed.), Categorias da narrativa. Lisboa, Arcádia: 81 define como "o lugar onde 
Mas é principalmente voltada para a descriçẫo dos espaços que a écfrase cumpriu um percurso diacrónico. Espaços que podem ser, antes de mais, públicos. Se o relato incide num espaço ou edifício concreto, da realidade imediata, claramente identificado, a relaçáo de fidelidade que possa existir entre o modelo e o seu retrato literário levanta o problema do 'realismo'. Com a noção clara de que à ficção é permitida uma liberdade recriativa, uma mimesis flexível, que não se confina a uma reprodução acrítica do concreto ${ }^{11}$, M. Carvalho arreda como inúteis os desajustes que daí possam advir e convida, graciosamente, a realidade a adequar-se à ficção (35):

Se a cadeia de Pinheiro da Cruz não for exactamente assim, convido desde já os Serviços Prisionais a conformarem-se ao texto, ou pelo menos a absterem-se de polémicas incómodas e derivativas do que lhes interessa a eles e a mim.

Mas se o espaço for privado, o mesmo é dizer meramente ficcional, em vez de problemas de verosimilhança outros se colocarão, a dimensão do excurso, como o tipo de pormenor que contempla, por exemplo. O sentido da moderação e do bom gosto é, neste caso, fundamental:

Não disse tudo sobre a mobília, mas acho que ir mais longe era exagerar ... (47)

Eu vou agora explicar como se dispunha a biblioteca, mas não dissertarei sobre labirintos e serei seco e desmunido de alegorias. (135)

E outro tanto se diga se for a personagem o motivo da écfrase (85):

Um escritor estilista dedicaria umas boas três páginas a descrevê-la, com gestos, saltos, risinhos, urros e queda de objectos. Eu por aqui me fico.

\footnotetext{
a narrativa se interrompe, onde se suspende, mas igualmente o espaço indispensável onde se 'põe em conserva', onde se 'armazena' a informação".

11 Halliwell, S. (1968), Aristotle's Poetics. Chicago and London: 16 fala, no que respeita à poesia como também às artes visuais, de representação, como recriação ficcional da realidade, de preferência a imitação, uma concepção mais elementar, que copia, mas não acrescenta, de uma verdadeira criação artística, valor extra, originalidade ou traço identitário.
} 
No anonimato de um 'escritor estilista' vai a alusão a um elemento de estilo, a écfrase. Por natureza extensa, retalhada em pormenores de adorno, de visível redundância e inutilidade, a menção que lhe é feita contrasta com o laconismo de que o nosso autor se afirma adepto. O seu modelo, sem dúvida o bom, porque breve e directo, exprime-se na secura, também paradigmática, de uma outra teorização: "Eu por aqui me fico".

O que, na tradição literária, eram sobretudo cores, dimensóes e formas, dos canteiros do jardim, das linhas de um quadro, de um edifício ou de uma escultura, pode tornar-se, na descriçáo de um ambiente contemporâneo, circunscrito à aridez de 'marcas e proveniências' (82); a loja, o endereço, o fabricante, eis os dados compatíveis com os interesses de um público consumista. Para tal, o nosso autor confessa-se sem talento ou competência, nem sequer vontade de promover aquela 'investigação' que o relato literário responsável requer.

Francamente, acho que estas personagens não merecem que se lhes faça o jeito e o leitor há-de ser poupado àquilo de que se não precisa, porque, tal como eu, se está nas tintas para as emblemáticas comerciais.

Tal como para o anacoluto, esperado mas não consumado, também a écfrase pode ganhar eficácia pela ausência (84):

Eu preparava-me agora para descrever melhor o gabinete do Bernardo, e já ensaiava vários ângulos, com movimentos cinematográficos do olhar, a que não faltava um contrapicado, quando alguém ...

E uma vez mais narrativa e cinema são aproximados por técnicas comuns. Se no caso do flash-back foi o cinema a retomar uma prática já homérica, na descrição ou exposição de ambientes o movimento foi o contrário. Com a sua eficiência visual e capacidade de escolher ângulos de maior sentido estético, é o cinema quem pode contribuir para uma estética retórica despojada e impressionista. Independentemente da dimensão, da perspectiva, da focagem, há que reconhecer que séculos de ensaio e de experiência abonam da importância e mestria da retórica descritiva. Ultrapassando eventuais críticas ou divergências, M. Carvalho aplaude, neste particular, a tradição (119):

Isto merece a sua pincelada, arrenegando daquele célebre teórico que mandava galgar as descriçóes. 
Rendido à sedução da arte de escrever, o autor admite apenas a exclusão de um bom excurso quando o volume de episódios, numa certa fase da intriga, vai já longo e o risco de excesso espreita (166-167):

Ainda bem que naquele dia sucederam a Jorge (...) eventos dignos de mençáo. Náo fosse este um dia em cheio - do ponto de vista do narrador - e lá teria eu de semear acontecimentos pelo livro fora. Assim, posso permitir-me condensar tudo nesta secção ...

Ao controle dos acontecimentos, do seu tempo e do seu espaço, está o narrador omnisciente ${ }^{12}$, uma presença sensível, declarada, interventiva. Colocado acima das figuras que agem no romance, está-lhe acessível a descrição de espaços que nem ele, nem a sua personagem, conhecem. Assiste-lhe o "à-vontade" de imaginar, vencendo os limites da própria realidade (35), um lugar onde nunca nenhum deles penetrou; permite-se devassar a intimidade da personagem e revelar o que o seu Joel Strosse quereria manter sigiloso ("um narrador omnisciente tem as suas vantagens. Se o narrador náo fosse omnisciente não saberia deste particular porque, quando o filho foi detido, julgado e condenado a sete anos de cadeia (...), Joel conseguiu manter um segredo quase total", 35); gracioso 'quase', traçando a irremediável vantagem do narrador omnisciente sobre a personagem. Controla-lhe qualquer movimento ("eu sei onde é que o Jorge Matos estava" (45)); pode navegar entre o passado e o futuro, ou calendarizar cada etapa dos acontecimentos dentro da intriga (82):

... porque enquanto eu descrevi e perorei, já se passaram três horas ...

Ocorre-me que ainda não contei como deve ser o caso do senhor bispo de Grudemil e, enquanto conto e náo conto, o Rover, beneficiando das vantagens do tempo narrativo, ajudado das aceleraçóes do fotógrafo, já irá derrapando por alturas de Alverca. (105)

Além do controle do tempo, dos espaços, da coesão da intriga, o narrador é ainda responsável pelo tom e pela verosimilhança que caracteriza em geral a narrativa. Comecemos pelo tom. Ao elogio que a descrição, mais ou menos extensa, mas sobretudo esteticamente eficaz, já mereceu, M. Carvalho contrapóe o laconismo singelo, rápido, por demais esquelético, a tocar as raias

12 Cf. Reis, Macário Lopes ${ }^{7} 2007:$ 174-177. 
do simples apontamento em alíneas. Talvez a linguagem jornalística tenha, tacitamente, neste padrão extremo a sua responsabilidade (112):

Agora há uma passagem muito rápida em que se contam uns pormenores relevantes que me convém despachar antes de rematar a primeira parte do livro (...). Se não fosse abusar, até usava alíneas e limitava-me a substantivos.

Tais excessos parecem convir a um estilo pós-moderno, o da geraçáo do correio electrónico e das SMS (112):

Mas como costumo ficar incomodado das habilidades modernaças, armadas ao pingarelho, com que a minha concisão poderia confundir-se, forço-me, por disciplina, a debitar texto, embora escasso.

Por outro lado, a tentaçáo de sobrepor convençóes parece, por vezes, irresistível. A condução perigosa de um repórter, fanático de aceleraçóes e derrapagens, insinua no narrador o deslize para outro contexto, o da "criminalidade literária" (104). Entre as duas situações, a diferença é tão só de grau. O escuro da estrada e o reflexo dos faróis nas árvores sugerem um "ambiente tétrico"; nos ramos, a imaginação projecta "mãos vegetais, nodosas, aduncas, malfazejas"; o ruído do motor talvez abafe imaginários "uivos agoirentos ou uma gargalhada de estalo". Neste contexto, a tentação progride no narrador "omnipotente" (104):

Boa ocasiáo para eu dar cabo da Eduarda e já agora do fotógrafo que, também, não se perdia grande coisa.

O cinema regressa como parceiro natural da narrativa literária, colocadas ambas as artes perante o factor 'verosimilhança'. Já Aristóteles (Poética $\left.1451^{a}-1451 b\right)$ se apoiava na verosimilhança para estabelecer um contraste entre poeta e historiador:

É evidente que a função do poeta não é contar o sucedido, mas o que podia suceder e o possível em virtude da verosimilhança ou necessidade (...). O historiador narra o sucedido e o poeta o que poderia suceder.

É, de certa forma, com palavras equivalentes às da velha Poética que M. Carvalho recorda a regra da 'verosimilhança', mas para sublinhar quanto a 
realidade por vezes excede a ficção no seu capricho; numa subversão entre 'realidade' e convenção literária, escreve (84):

O que eu passo a contar agora é inacreditável. (...) A vida, não raro, ficciona, devaneia, absurdiza e eu hei-de conformar-me a ela mais do que ao famoso pacto de verosimilhança outorgado com o leitor. ${ }^{13}$

A verosimilhança pode retratar a realidade, salvaguardando no entanto a vantagem de escamotear alguns dos problemas que lhe perturbam o curso e, por isso, "programando" as etapas da história isentas de inúteis embaraços. Outro tanto faz a arte parceira, o cinema, deitando máo de recursos semelhantes que abreviam e aplanam a narrativa, ainda graças à omnipotência do autor (94-95). Enquanto, no cinema, "os automobilistas encontram sempre um lugar a jeito para estacionar, mesmo no centro de Lisboa", também "o autor totalitário" tem artes de garantir que "as pessoas estão sempre em casa quando são precisas" e assim se poupa a pormenores desnecessários e ao seu leitor algum enfado:

Imaginem as voltas e o esforço em que eu me veria enrolado se o Nunes não estivesse disponível. Teria que repetir telefonemas, encontrar mais situaçóes, mais ambientes, mais pretextos, mais conversa e enquanto assim ia gastando o papel, com ele iria gastando também a paciência do leitor, que participa da natureza dos bens escassos.

A compensar excursos e delongas, o autor de Era bom insiste na vantagem do laconismo e da narração enxuta. Mas o inverosímil em literatura pode ir, naturalmente, muito mais longe do que o simples garantir da eficácia e brevidade do relato; pode exactamente proporcionar o efeito contrário, com a introdução do elemento fantástico, correlato com um aparato estilístico condizente. O sonho - com toda a sua convenção que vem da épica mais tradicional, a homérica, ganha fôlego com o teatro antigo, sobretudo trágico, e não deixa de penetrar géneros posteriores como a já mencionada novela grega da época helenística - constitui um bom

13 Scodel, R. (1999), Credible impossibilities. Conventions and strategies of verisimilitude in Homer and Greek tragedy. University of Michigan Press:1-31 distingue entre verosimilhança e credibilidade; no primeiro caso, a autora fala da conexáo que o texto cria com o que o destinatário entende por realidade; por credibilidade, por outro lado, exprime-se a aceitação que o público tem de assumir a convenção, as regras do género, o que torna consumível a ficção. 
exemplo de 'inverosímil'. Conhecemo-lo, como um processo de introdução do sobre-humano, como profecia de futuro, como retrato da consumação de um destino temível. No contexto literário, o sonho tem, em geral, um duplo efeito: o de desencadear sobre quem o recebeu uma reacção emotiva, e o de preparar o leitor / espectador para o desenvolvimento previsível da acção. A sua expressão comporta sempre uma narrativa, a da visão tal como ela se revelou, com todos os factores de ambiguidade que lhe são próprios, seguida de uma tentativa de interpretação. Ao lado das profecias ou dos presságios, o sonho faz parte de um código de sinais que transmitem do além a vontade dos deuses ou do destino.

$\mathrm{O}$ sonho, como o vislumbra $\mathrm{M}$. Carvalho, é contrário à melhor tradição antiga, onde o misterioso e o transcendente que lhe estão na natureza convêm mais ao ambiente recolhido da noite e à privacidade do leito. Porque rodeado de silêncio, de solidão e de treva, o ser humano tem melhor capacidade de percepçáo, todo concentrado que está sobre a mensagem que o aborda. Por isso a visão, como um raio de luz em plenas sombras, contrasta com o ambiente em volta e estimula a famosa dicotomia trevas / luz, com todas as conotaçóes objectivas e subjectivas inerentes. A reacção do sonhador é constante, impóe a comunicação, exige a confidência, necessita de um intérprete. Em geral, os sonhos têm uma forte componente visual, exprimem-se por imagens sem palavras, mas capazes de falar pela expressividade dos símbolos que usam. Sáo, portanto, apelativos ao sensorial, breves na comunicação, valorativos apenas de alguns elementos sobre os quais retêm a atenção do seu destinatário. Mas primam pela ambiguidade, sobre que o espírito é chamado a pronunciar-se face às aparências captadas pelo sentidos ${ }^{14}$. A M. Carvalho é o seu contorno fantástico, mais do que a simbologia de que o sonho é portador, o que lhe suscita o comentário (33):

Vinha a calhar agora um sonho, com multidóes, cânticos e bandeiras e umas irrupçóes disparatadas (...), para dar verosimilhança ao sonho que, por definição, é inverosímil e portanto só com inverosimilhanças é que se aceita, embora as verosimilhanças que vão de par com as

14 Sobre a potencialidade dramática dos sonhos, vide Devereux, G. (1975), Dreams in Greek tragedy. Oxford, Basil Blackwell; Lévy, E. (1983), "Le théâtre et le rêve: le rêve dans le théâtre d'Eschyle", in Zehnacker, H. (ed.), Théâtre et spectacles dans l'Antiquité - Actes du Colloque de Strasbourg. Leiden: 141-168; Pereira, S. M. (2008), "Poética dos sonhos e das visōes em estado de vigília - I", Humanitas 60: 11-28; idem, "Poética dos sonhos e das visóes em estado de vigília - II", Humanitas 61: 5-18. 
inverosimilhanças estejam carregadas de sentido e de piscadelas de olhos, quando não são as inverosimilhanças que batem certo com os dicionários de símbolos de que, por acaso, nem tenho nenhum exemplar à mão.

\section{$\mathrm{O}$ retrato e a acçáo das personagens}

A par das estratégias narrativas, o autor tem de preocupar-se com o desenho das personagens, os agentes da acção. Também Aristóteles (Poética $\left.1451^{a}-1451 b\right)$ lhes reconheceu a importância e doutrinou sobre a sua criação:

O universal - que é próprio da poesia e da ficção, acrescentamos nós - consiste em estabelecer a que tipo de homem corresponde dizer ou realizar tais ou tais coisas em funçáo do verosímil e do necessário, um objectivo a que a poesia aspira apesar de impor nomes próprios às personagens.

Sublinha Aristóteles o carácter paradigmático da personagem, que mantém a universalidade de um tipo oculta por trás de um nome, que, no âmbito da ficção, a individualiza. Há depois a compatibilidade - ou 'verosimilhança' - a observar entre o tipo e a acção e palavras que lhe são atribuídas. Assim se define, no essencial, a 'veracidade' da personagem.

Importa, em primeiro lugar, escolher as personagens que melhor convêm a um enredo. $E$, aí, a convenção de muitos séculos tem uma palavra a dizer. Desde sempre, a tradição privilegiou a personagem num determinado contexto, familiar e social. Assim o ressuscita M. Carvalho (26):

Habitualmente ocupamo-nos de histórias de famílias, avôs, tios, primos, cunhados, uns bons, outros maus, cartas antigas a forrar baús, mansôes vetustas a que se regressa e essas coisas ...

A estratégia fica patente: figuras múltiplas, unidas pelo parentesco, e sobretudo contrastantes, pela maior ou menor proximidade familiar, por condicionalismos éticos e etários, ou de género, a justificar conivências ou conflitos. O movimento tradicional do nostos, o regresso à "mansão vetusta" que é o ponto de referência da acção - esquema de que a Odisseia é o primeiro marco na literatura da Europa -, como também a carta, a 
permitir contacto, aproximação ou reconhecimento ${ }^{15}$, são elementos que a tradição usou sem esgotamento neste jogo de interacções. À tradição, porém, M. Carvalho responde com a necessidade de refrescamento, de renovaçáo, que aproximam o agente da acção do leitor e tornam, por isso, os acontecimentos mais próximos, perceptíveis e mobilizadores (26). Estamos num terreno equivalente ao que Eurípides proporcionou, na reformulação que também ele fez, na tradição trágica, do elenco de personagens, o dos oikeia prágmata (Aristófanes, Râs 959), 'temas caseiros', porque envolvem parentes e porque são 'familiares' ao espectador.

... e esquecemo-nos de passar pelas ruas, com atenção penetrante, e deixar à posteridade uma nota de verismo bem documental.

À tipologia do factor humano, que tende a ser contínua e, no essencial, eterna, o contexto pode trazer a tal veracidade e actualização. Por mais ficcionais que as figuras de Era bom sejam, mesmo se passadas por um banho de modernidade, tornam-se presentes e palpáveis na moldura da bem conhecida Costa da Caparica. O real próximo e a ficção sobrepóem-se em perfeita harmonia (81):

A Costa atrai um bom número dos nossos concidadáos que adoram aquilo. Imaginai-os a cirandar por lá, do modo palonço que foi descrito, e as nossas personagens fazendo vida entre eles.

Dos modelos convencionais, o autor de Era bom arranca um exemplar famoso, o par do velho / jovem, pai / filho (40):

Quando um homem de cinquenta anos se póe, inevitavelmente, a deitar contas à vida e a considerar com melancolia que na Idade Média ou na Antiguidade seria já um anciáo provecto à beira da cova ...

A menção explícita do passado vem datar o exemplo com milhares de anos. Dessa tradição, muitas vezes fundamentada no que reconhecemos como 'conflito de geraçôes', M. Carvalho valoriza sobretudo a continuidade;

15 Sobre a tradiçáo literária da 'carta' desde a literatura grega antiga, vide Silva, M. F. (2008), "Mensagens, cartas e livros no teatro grego antigo", in Matos, M. C. (ed.), Helénicos. Estudos em homenagem do Prof. Jean-Pierre Vernant (1914-2007). Lisboa, Edições Távola Redonda: 227-260. 
e, dentro de um espírito com raiz na literatura da Grécia Antiga, sublinha a ideia da caducidade da vida, da finitude da criatura efémera que o ser humano é, por natureza e destino; e é essa efemeridade que os filhos ajudam a combater como "procuradores e mandatários da progenitura" (40). Esta é ainda a ambição do Joel Strosse, personagem central no romance em análise.

Feita a escolha, segue-se o desenho que, na literatura ao contrário de artes mais ligeiras, de traços leves, como a banda desenhada por exemplo, exige "espessura" (124). Objectivo esse que se pode atingir por diferentes caminhos. Dar voz e movimento às próprias personagens será, certamente, um deles, consentâneo com o drama, mas a que o romance deu continuidade. Outro será sobrepor-lhes a tal "omnisciência" do autor e esquematizar, como em retrato a que se irá conferir um sopro de vida, as suas linhas de força como preâmbulo à acção (18); com Rui Vaz Alves e Joel Strosse Neves na sua mira, e depois de proceder, entre ambos, a uma hierarquização a que não falta ironia - "Rui Alves é vogal da administração e dirige o "departamento de contacto" da casa; o outro chama-se Joel Strosse Neves, e estancia habitualmente num dos pisos de baixo e tem, sobre o primeiro, a única vantagem de ser o protagonista desta história" -, M. Carvalho afirma-se como narrador responsável pela apresentação das personagens:

Como, neste breve relance, os dois homens estão apenas a olhar um para o outro, e náo adiantam nada, eu aproveito a ocasiáo para me prevalecer de uma velha tradição literária e apresentá-los ao leitor, com o acrescento de umas circunstâncias esclarecedoras.

"A velha tradição literária" que o autor invoca para a descrição das personagens pode recuar até à mais antiga épica europeia, consagrada sob o nome de Homero; mas virá a ter, no romance helenístico, uma reconhecida expansão. A mesma técnica, que permite desvendar intençôes e sentimentos ocultos das personagens, tem expressão em fórmulas, como "eu entretanto vou-lhe cortando na casaca” (95), a preceder a apresentação descritiva da figura.

O grau de "espessura" da personagem depende também de uma opçáo do autor e M. Carvalho decide por o que se poderia chamar um padrão impressionista: pôr de lado excessos descritivos para se centrar nas linhas de força de um retrato, eis a opção que reiteradamente assume:

Por agora, traço-a assim em pinceladas rápidas, de zarcão, despachadamente, não me atardo nos pormenores, prescindo das espessuras, não me distraio com as cores e as luzes e vou muito direito à finalidade. (59) 
Eu não queria entrar muito em pormenores psicológicos, porque tenho pressa, e prometi não aprofundar em excesso esta figura, mas talvez não seja despiciendo sublinhar aquilo que já está percebido ... (61)

Esta sobriedade na descrição é, sem dúvida, uma porta aberta ao agir e falar da personagem, de modo a que o leitor tire, por si, conclusóes.

Criada a figura, há que imprimir-lhe vida, acção e também interacção. Mais do que agir, a personagem integra-se num todo, onde deve também interagir. E essa articulação, de que depende o fluir da intriga e a consolidação de sentidos na narrativa, é vital no romance (67):

E assim se estabeleceu o contacto entre Eduarda Galvão e Jorge Carreira Matos, aprestando-se uma ligação nesta história, que já nela tardava.

Mas uma outra interacção é habilmente consciencializada, entre o autor e a personagem. Por vezes, entre ambos parece gerar-se uma intimidade, que os aproxima e sentimentalmente os envolve (114):

Baixo a guarda, mudo de registo, vem-me até à ideia interpelá-lo e tratá-lo, por instantes fugazes, na segunda pessoa do singular.

O espaço da ficção parece então reduzir-se e permitir que, "do seu Olimpo", o autor penetre no próprio contexto intradiegético. Numa focagem que tudo tem de 'fílmico', o autor procura o melhor ângulo de observação:

Deslizo cá do meu Olimpo e instalo-me por ali, naquela sala pelintra, talvez junto ao canto superior esquerdo, encostado ao tecto, ao lado da empena, que é sítio azado para tudo ver, pese embora a mancha de humidade.

Mas mais não pode o seu esforço do que observar de perto e atentar particularmente na personagem. A distância que os separa - realidade / ficção, narrador extra e intradiegético / personagem - é intransponível.

Apercebo-me de que é inútil querer chegar ao contacto com o Joel Strosse. A minha voz não seria ouvida, as minhas mãos atravessá-lo-iam, como as de um fantasma (...). Tenho de limitar-me a perscrutar, a conjecturar, a espantar-me, sentindo-me, porém, mais próximo dele, 
do que nesta frieza neutra sentado à minha secretária. Joel existe, eu não. Com este estado de coisas me hei-de confortar.

E atingimos o cerne da questão, aquele momento em que o autor dá autonomia à personagem e lhe inspira gestos e palavras. A coerência é então uma imposiçáo; definido um tipo humano, todos os comportamentos que se lhe atribuam devem obedecer a uma compatibilidade convincente. Que o autor reflicta sobre possíveis reacçóes da personagem num dado momento e justifique a sua opção é o reconhecimento dessa mesma regra (78):

Dramático e surpreendente! Se fosse ocasiáo de mordacidades ter-lhe-ia respondido Jorge no espírito dos tempos. (...). Porém, Jorge não era mau tipo, como eu, de resto, já preveni umas páginas antes, de maneira que optou por um regozijo moderado.

Há momentos em que é no silêncio, melhor do que em qualquer outra manifestação, que a expressividade do episódio assenta. De efeitos reconhecidos desde a Antiguidade, o silêncio contém um potencial de expressóes ambíguas - luto, temor, sofrimento -, que, em última análise, impóem o corte com a realidade em volta ${ }^{16}$. Mas nem por isso falta à mudez da personagem um interlocutor, na pessoa dos que a cercam (dentro da ficção) ou a observam (dentro e fora do contexto narrativo), incentivados à surpresa e especulação sobre o enigma que o silêncio contém. É esse o desafio que M. Carvalho coloca ao seu leitor, esgrimindo com um processo que continua vigorosamente actual (77):

Houve um silêncio comprido que eu náo sei como qualificar. Talvez, em explicando como as personagens se encontravam e o que faziam, possa alguém, mais hábil que eu, encontrar a qualificação para o silêncio que é, da Língua Portuguesa, a palavra mais difícil de adjectivar novamente.

"Comprido" é o qualificativo imediato, que assinala a característica mais evidente e constante do "silêncio", literário ou dramático. Mas, além

16 São sugestivas as palavras de Várzeas, M. (2001), Silêncios no teatro de Sófocles, Lisboa: 12, sobre o assunto: "Podemos considerar o silêncio um signo pertencente ao código retórico-estilístico, que funciona como uma espécie de grau zero da linguagem, com idênticas potencialidades expressivas. Idênticas ou até superiores, visto que suscitam uma emoção específica que as palavras não são capazes de produzir da mesma maneira, com o mesmo carácter de contenção e urgência, digamos assim". 
da evidência superficial, é na profundidade e amplo espectro psicológico que a fluidez é grande e os qualificativos múltiplos e indefinidos.

À convenção do silêncio opõe-se a da linguagem. A modulação que lhe é exigida constitui um factor relevante como veículo de nuances emotivas de cada figura em concertação com o contexto variável em que se encontrem. Sem quebras ou incoerências, essas variaçóes respiram naturalidade e persuasão (81):

Já vejo que estas personagens estáo num momento miudamente agitado das suas vidas. Os acontecimentos provocaram-nas e transtornaram-lhes o natural de hábitos e de pensamentos.

Mas há também, em consonância com a permanência de traços que a noção de 'tipos' humanos contém, uma convenção de linguagem; dessa, o atractivo reside no próprio reencontrar de fórmulas conhecidas ou até mesmo desgastadas, que se tornam transversais sob diferentes modalidades artísticas (113):

Esta discussão, infelizmente, não brilha pela originalidade. Fiz um traslado das objurgatórias que os casais da classe média, possuidores de automóvel, costumam trocar pelo menos dez vezes na vida. Acho que até há uma ópera sobre o assunto.

Por fim, inerente ao maior ou menor aprofundamento de cada retrato e ao mais ou menos dilatado espaço concedido a cada personagem, resulta a noção de figura primária - o protagonista - ou secundária. Ao protagonista cabe, por tradição, uma presença e actuação constante, que o identifica com o próprio fio da acção. Quando a diversidade de outras figuras ou episódios parecem, por momentos, arredá-lo da ribalta, uma reflexão do narrador pode contribuir para repor a hierarquia esperada (135):

Agora reparo que há muito tempo não falo do Joel Strosse, propriamente dito, que eu quis que fosse personagem capital nesta história e que tem sido sobremaneira negligenciado. Por onde andava ele?

Mas um outro traço, primário no esboço de cada figura, contribui também, soberanamente, para estabelecer distinçóes: o nome. A escolha de um nome para cada personagem é, em M. Carvalho, uma estratégia visível. Nomen omen - diziam os antigos - 'o nome é um presságio'; 
e esse continua a ser um pressuposto vital na narrativa do autor português. Mas se esta preocupação é, em si mesma, uma evidência comprovada por múltiplas opçóes - reveladoras de vulgaridade ou especificidade -, um comentário testemunha o que mesmo ao leitor mais desatento náo passa despercebido (87):

... a filha do Jorge, que aproveito para informar chamar-se Eufémia, nome cuja escolha não fora inocente.

Mais do que as ressonâncias etimológicas - Eufémia, 'a bem falante' -, são as conotaçóes políticas - a lembrar a célebre revolucionária, Catarina Eufémia - as que se patenteiam na escolha. A preferência ganha sentido se lembrarmos que o pai, o Jorge Matos, "esteve preso pela PIDE em 1973 e sofreu tratos de polé" (47), o que o incentivou a tornar-se um activista, "inventor de um método absolutamente inovador de colagem de cartazes" (47). Mesmo se superficial nas suas convicçōes, a tendência para se afirmar por exterioridades justifica também a escolha do nome para a sua herdeira. Mas, se atributo oportuno no retrato paterno, "Eufémia" é nome possuidor de uma tremenda ironia, se considerado o carácter da sua portadora, "dada em beata, missionária em São Tomé" (45). Por isso, o mesmo pai que a baptizara augurando-lhe revolucionário futuro de inconformismo, procurava diluir-lhe tendências tão claramente conservadoras sob uma referência ambígua (87): "Jorge apressou-se a dizer que ela estava colocada em São Tomé, numa missão internacional": fórmula de uma ambiguidade muito mais promissora e estimulante de prestígio.

Em contraste com a impressão produzida pelo nome está o resultado, não menos efectivo, do anonimato. Este pode ser articulado com a natureza de uma personagem secundária, aquela que não detém mais do que um lugar obscuro. É o caso do "professor de Grego", uma brilhante construção de M. Carvalho (153):

Então aquele professor de Grego não tinha nome? Acho que já o vai merecendo, pelo seu esforçado protagonismo, a querer à força entrar na história. Como é que ele se há-de chamar? Pensando bem, fica-lhe a calhar Vasco Reboredo, mas não há-de passar além de seis páginas, se tanto, embora exemplares.

Com o protagonismo pontual que lhe é afectado, prioridade num episódio mesmo que de dimensão comedida, a figura sai do simples anonimato 
tipológico - qual Ama, Mensageiro ou Servo da antiga tradiçáo - para assumir maior autonomia e "espessura" e, por essa via, reclamar um nome. E esse, conservador, com laivos de excepção, é o que melhor convém à figura exótica do professor de Grego.

\section{O domínio da linguagem}

De entre o que pode chamar-se 'lugares comuns', o cliché mereceu a A.-M. Perrin-Naffakh ${ }^{17}$ uma definição simples e apropriada: "O cliché é - na linguagem, nas artes, nas ideias e nos costumes - o espaço de opçôes reveladoras entre tradição e inovação". Configura-se como uma ideia convencional, provinda do passado, que uma sociedade tende a repetir, sob forma de uma expressáo institucionalizada e estereotipada. E. Rabaté ${ }^{18}$ pode ainda concretizar, apelando agora à forma do cliché: "Pertence, antes de mais, à língua comum (...); é, além disso, um fragmento de língua morta, desvitalizada, ou pelo menos adormecida (...); é, por fim, característico de uma língua fixa, que conserva, como palavras congeladas, antigas figuras e possui (...) uma rigidez ameaçadora”. Mas nesta sua vulgaridade e fixação, o cliché está aberto à criatividade literária, em primeiro lugar como alvo de caricatura, mas também como fonte inspiradora para reformulaçóes ou glosas ousadas. Conclui, com pertinência, G. M. Rio-Torto" ${ }^{19}$ " “...o cliché é ao mesmo tempo fonte e manifestação de criatividade e cristalização”.

Em Era bom, o lugar-comum tem o seu espaço de prestígio e uma versatilidade bem explorada, de que o primeiro sintoma, tardiamente justificado, está no próprio título do romance (160):

Eis a Vera Quitério ao telefone (...). Vai dizendo "hum-hum, hum-hum..." e anotando, sisudamente. De vez em quando fala e declara: "pois, pois, era bom que trocássemos umas ideias sobre o assunto ...". No decorrer da presente conversa, ora isoladamente ora no meio de outras frases que pouco interessam, esta expressão surgirá repetida. É aquilo a que metaforicamente, na prosa fradesca, se chama "um bordão de linguagem". A ele voltarei porque, dando o título ao livro, merece alguns desenvolvimentos.

\footnotetext{
17 (1996), "Le langage cliché: aveu d'usure ou pouvoir d'écho". Confluências 14: 7.

18 (1996), "Henri Michaux et le cliché: résistance et fascination”. Confluências 14: 62.

19 "Linguagem e clichê", Confluências 14: 160.
} 
Associado à frase, M. Carvalho anuncia "o bordão de comportamento" $(160,162)$, ampliando a palavra repetida com o gesto mecânico de tomar notas, traços caracterizadores de uma secretária. Por enquanto, o idiotismo é ainda e tão só a repetição atípica, expressiva de uma rotina falha de imaginação ou de criatividade. Mas desengane-se o leitor e aguarde, adiante, o desenvolvimento prometido; porque não só não se trata do repetir inconsciente de um dito comum, como exigiu à sua autora, a Vera Quitério, uma aturada elaboraçấo. Como quem conhece bem os caminhos a percorrer para conseguir expressóes cristalizadas, M. Carvalho atesta a originalidade da sua personagem (165):

Eu já fiz uma detalhada investigação sobre a matéria dos auxiliares de frase, recolhi milhares e milhares de expressões, consultei alguns tratados, nacionais e estrangeiros, e ainda náo encontrei referência a alguém que usasse um "bordão" tão arrevesado, nem explicação para o mesmo.

Da construção de fórmula tão estranha nos dá conta o autor. De um simples e bem alentejano "n'é?", "nasalado e musical no final das frases", um banho de capital partiu à recuperação de um pleno "não é verdade?", que flutuou com um "não sei se estás a ver?", ou, ainda melhor, "não sei se estás a apreender a ideia?". Na fuga a que se propóe da banalidade rasteira, a Vera Quitério investe com efeitos socializantes e com um esforço de conformação profissional, que o autor escalpeliza. Primeiro a suavização do que pudesse soar a uma impertinência descabida: "Estou em crer que a bondade natural da Vera acabou por achar aquele "há que discutir" demasiado imperativo no "há que", e demasiado conotativo de desavença no "discutir". O subconsciente dela deve ter amaciado o "há que", sobremaneira seco e autoritário para um mais urbano "era bom"'; depois a tentativa de evitar qualquer confronto verbal: "”Era bom que discutíssemos" poderia, talvez, dar a ideia de desafio para uma boa zaragata. De maneira que Vera há-de ter preferido o eufemismo do "trocar ideias"; faltava-lhe o necessário complemento e daí o "sobre o assunto"”. Eis o milagre do surgir de um bordão, onde se mesclam sensibilidade, rigor profissional, imaginaçáo, polimento, que podem transformar um simples "n'é?" em algo realmente criativo e pessoal: "Era bom que trocássemos umas ideias sobre o assunto". Podemos, com esta liçấo de linguagem, perceber quanto, a partir do enunciado imediato do título, a expressáo e o estilo estấo nas prioridades do autor do romance. 
É no plano lexical que a estabilização do lugar-comum assenta; depois de condicionar o nome, fixa, junto dele, o qualificativo ou epíteto. A raiz do processo pode estar num uso que suscitou atenção e popularidade; veja-se o exemplo sugestivo do epíteto, que se pode tornar logótipo, de uma cidade. Foi de um cineasta suíço que Lisboa ganhou o estranho epíteto de "cidade branca" 20 , "confundindo-a porventura com Évora, ou com Campo Maior" (16). Apesar de desajustado à realidade, o qualificativo beneficiou da liberdade devida aos criadores (17):

Aqui há que condescender com convicções entranhadas, tolerar as daltonias íntimas, garantir a liberdade poética, libertas uatum.

Liberdade de que beneficiam os criadores de arte em geral, não apenas os cineastas, mas com certeza também, em graus diferentes, os escritores. Ou não terá João de $\mathrm{Melo}^{21}$, autor de ficção, num dos seus livros, o direito de asseverar que "o mar é branco", sem que haja direito a corrigi-lo com um "branca é a espuma"? O que poderíamos chamar 'opiniáo criativa', na atribuição de um epíteto visual, detentora do direito de confundir o objectivo - Lisboa não é branca - com o simbólico - mas é, tal como Évora ou Campo Maior, símbolo de um sul com traços mediterrânicos -, influencia a 'opiniáo colectiva' e pode impor, como estereotipada, uma forma de narrar (16):

As pessoas comuns têm destas coisas ... Deixam-se levar pelas declaraçóes de gente prestigiada, mesmo quando a gente prestigiada se deixou iludir por impressóes fugidias e sacudidas pela sequência de fusos horários ...

20 A aproximação entre a literatura e o cinema é frequente em Era bom (cf. 183-184). A incapacidade que as palavras denunciam em certas circunstâncias é facilmente suprida pelo poder, outro, da imagem e do som. E quando as duas artes se associam ou sobrepóem, há que proceder aos inevitáveis ajustes (184): "Se fizerem um filme deste romance quero-o, nesta passagem, expressionista, de estúdio, cheio de efeitos, com muito papel pintado, e habilitado a palavras sagazes dos Cahiers du Cinema, ou de quem quer que os substitua".

21 João de Melo, nascido nos Açores em meados do século xx, tem dedicado a sua atençấo literária sobretudo ao romance e ao conto. Muito marcado pela experiência de uma campanha em África em tempos de guerra do Ultramar, tornou este um dos motivos fortes na sua criação, a par de elementos dedicados aos Açores, sua terra natal. $O$ meu mundo não é deste reino (1983), Autópsia de um mar de ruinas (1984), Entre pássaro e anjo (1987), Gente feliz com lágrimas (1988), contam-se entre os seus títulos mais conhecidos e premiados. 
Fascinada pelo impacto da fórmula, afinal obra de "um autor fatigado", a multidão cede ao atractivo das palavras e mergulha, sem crítica, na própria ficção:

Há gente a reparar no título que não na fita, e a olhar em volta, ninguém.

Simples elementos de superfície são consumidos como indícios de profundidade intelectual, quando se trata de mero aparato, tendencialmente instável e caduco. Logo o epíteto "branca" se confronta com outro, consagrado por uma tradição mais longa, "cidade de mármore e granito", ao mesmo tempo que uma anónima gente prestigiada ganha nome, Alexandre Herculano $^{22}$. A ironia é neste caso tanto mais forte quanto o perfil literário de Herculano o vincula particularmente com a história, o que lhe exigiria um mais estrito respeito pela verdade. Também Herculano se deixou arrastar "por uma imaginação romântica", e pôs mármore e granito onde nunca existiram. Mas nem por isso deixou de consagrar a expressão num tempo datado, um século e meio, que divulgou, repetiu, fixou a expressão que pareceu, esteticamente, feliz. Em diferentes contextos, públicos e privados - "nos discursos oficiais, nos arrebatamentos de bodas e baptizados, na retórica de alguns professores de liceu, e na conversa dos anciãos ao adormecer de netos" -, as palavras de Herculano foram acriticamente repetidas, como fórmula feita ou palavra passe de uma certa época ${ }^{23}$. Primeiro oficial, progressivamente mais popularizada, a expressão repetida decai e fociliza-se, como antiquada. Escapa-se-lhe então o colorido literário e avulta nela o desajuste prosaico. Para salvaguardar, mesmo assim, a respeitabilidade do secular historiador, M. Carvalho condescende até em reconhecer, entre os tons diversos da cidade, "as suas brancuras aqui e além, preciosamente colocadas, para servir o todo" (17). Numa palavra, o diálogo entre a realidade e a criação literária faz-se a vários níveis, dentro de uma tradição mimética de que Aristóteles é um primeiro testemunho (vide supra 10-11). Arriscando, por sua vez, um novo epíteto, M. Carvalho, com a liberdade que lhe dá o estatuto de autor de romance, avança com o "magenta", uma cor, de resto, muito do seu gosto literário ${ }^{24}$. E defende (17):

22 Expressão usada em $A$ voz do propheta (1837), mais tarde reeditada em Opuisculos (1873).

23 É o que Perrin-Naffakh 1996: 10 refere como "certos tipos de linguagem que uma época ou um meio póem em moda durante um tempo".

24 Que consagrou, mais recentemente (2008), no título de um romance, A Sala magenta. Lisboa, Caminho. 
O que importa asseverar agora é que, ainda que a cor magenta não venha nos dicionários, o que quase a candidata à inexistência, lançada naquela rua, desmerece tanta gritaria e ignorância.

Reserva-se, assim, o autor a liberdade de ir além de uma linguagem padronizada. E decerto, como com o cineasta suíço ou com o historiador Herculano, também o seu magenta - tão ficcional como o branco, o mármore ou o granito - há-de colher os seus adeptos e conhecer a fixidez, em todas as vozes e monitores, totalmente popularizada (17):

Alto, que querem pintar de cinzento o célebre prédio magenta da rua tal ...

Deixemos a linguagem da arte e passemos à do simples quotidiano, onde o cliché prevalece. Alguns incrementos de estilo se associam à insistência repetitiva. Assim a hipérbole, que condimenta uma frase de ruptura afectiva como "o meu filho, para mim, morreu" (41). Em consonância com o que afirma P. Jourdan ${ }^{25}$, que não convém a um narrador talentoso reproduzir, de modo passivo, um cliché, também M. Carvalho recusa a frase convencional, obtendo um efeito paródico da própria suspensão (41-42):

Quase chegou a proclamar "o meu filho, para mim, morreu", mas conteve-se a tempo, ao perceber a teatralidade ridícula do lugar-comum e a falsidade dele.

Frase aliás vazia, em conflito com a realidade, "porque a fotografia de Cláudio lá continuava na Fundação sobre a secretária”.

Num contexto mais literário, "mede a sala a grandes passadas", (50) propóe uma solução déjà vue, verdadeiro tormento de quem se deseja criativo e original:

Mas francamente, receio que o leitor já tenha lido isso em qualquer lado. A quem escreve, faz sombra essa barreira constante, eriçada de farpas, daquilo que outros mais expeditos ou temporãos escreveram antes.

É essa a fronteira que separa o cliché, fixo e gasto, da capacidade de inovação. Para evitar um plágio desconfortável, o autor terá de empenhar-se

25 (1996), "Paul Valery chasseur de perroquets", Confluências 14: 51-59. 
no achado dos seus próprios lugares-comuns, fórmulas que, desde a épica homérica, apoiam a contextualização repetida de espaços, tempos figuras e suas características e acessórios. É no adjectivo que a excelência do processo assenta; o que opor a uma noite "cerrada, fria, tempestuosa", epítetos convencionais de um ambiente hostil e agoirento? Porque afinal sombras tais náo estáo previstas nesta narrativa, com isso se esvai a necessidade de inovar o epíteto ou de se adoptar uma fastidiosa repetição. É do mesmo adjectivo que surge o indesejável cliché no seu uso mais puro, aquele em que, alheado de qualquer sentido ou contexto, o qualificativo é accionado a propósito e despropósito. Nesse risco mergulhou a Eduarda Galvão, a periodista, fanática de um blasé que pronunciava (58)

com generosidade, aplicando-o a um universo de realidades, largamente excedentário do campo semântico competente. Considerou blasés o fotógrafo, o proprietário, o rapazito vestido de encarnado que ia levar pizzas à hora do almoço, e o cachorro de um vizinho que se equilibrava nas patas de trás.

Parece ser da natureza do lugar-comum o desgaste, mesmo quando criado expressamente pelo próprio autor. Em breve, o seu destinatário se dará conta da repetição, que lhe soa, já não a criação recente, mas a pura incapacidade (67):

E só não exclamou "o vinho está tirado, há que bebê-lo", porque eu já gastei a expressão umas linhas acima. ${ }^{26}$

Com o estilo colaboram algumas figuras de estética literária a que $\mathrm{M}$. Carvalho não se furta, ciente do efeito da tradição na expressividade. A metáfora surge, no catálogo, referida como recurso de excelência ${ }^{27}$. Em primeiro lugar, com a sua formulação própria - um "como" a anunciá-la

26 Vide 66.

27 Trata-se, de facto, de uma figura de estilo muito antiga, que Aristóteles, Poética 1457 b 6 define como "a transferência de uma palavra que pertence a outra coisa" (tradução portuguesa de Valente, A. M. (2004), Aristóteles. Poética. Lisboa, Gulbenkian), ou, mais adiante (1457b 13), "aplicar a uma coisa o nome que é de outra”. Já o autor da Poética $1458^{a}$ 20, considera também a metáfora como uma defesa contra a banalidade da linguagem e uma protecção contra o que é simplesmente corrente. Mas alguma parcimónia no seu uso (1458b 13) protege o discurso do ridículo. De entre os ornamentos de estilo, a metáfora é, em particular, "sinal de talento, porque construir bem uma metáfora é o mesmo que per- 
-, abunda nos textos que visam um leitor alargado, pouco exigente, habituado a uma literatura fácil (50). De facto, esta noção de que a metáfora é frequente, disseminada por todos os tipos de linguagem, de certa forma superficial, instrumento de floreado retórico pondera entre muitos estudiosos que dela se ocuparam ${ }^{28}$ :

E foi como se (este "como" não introduz metáforas, por ora, que as reservo para mais tarde ${ }^{29}$, talvez dedicando-lhes meio capítulo ou um inteiro, para conferir um toque de literaridade petite-bourgeoise, muito vendável, a este texto ...)

Dessas metáforas protocolares, a memória arquivou bons exemplos (103):

... contra um carro que lá vinha rápido, não apenas como o pensamento, à maneira do de Cardoso Pires ...

Com o tempo, a metáfora vai-se tornando um pouco saturante, no seu convencionalismo formal (88):

Indiferente às recriminaçôes (esparsa e passageira numa chuva de penugens negras, e vá de metáfora .......

Por fim, acaba susceptível a diferentes paladares, ora mais urbana e subtil, logo mais rústica e pedestre (141):

Jogar em vários tabuleiros! É esta subtil alegoria, decerto inventada por quem não percebe nada de exercícios escaquísticos (...) que me

cepcionar as semelhanças" (1459ª 6-8). Sobre a metáfora, vide ainda Lausberg, H. (1963), Elementos de retórica literária. Trad. portuguesa, Lisboa, Gulbenkian: 161-162.

28 Vide Gomes da Torre, M. (1992), “Acerca da tradução da metáfora”. Linguas e Literaturas 9: 212. No desmembramento e catalogaçáo que se tem pretendido fazer da metáfora, em tipos representativos das suas várias expressóes, é interessante registar a sugestáo de Netwark, apud Gomes da Torre 1992: 213: "Distingo seis tipos de metáfora: morta, cliché, tradicional, adaptada e original”. A aproximaçáo com o cliché é importante no contexto que temos vindo a desenvolver.

29 É curiosa esta táctica do que chamaríamos a 'promessa falhada' do autor; muito comum desde tempos muito recuados nas narrativas de grandes dimensóes - caso de Heródoto, por exemplo -, sinal de distracção do autor ou de incompletude da obra, este tipo de compromisso pode tornar-se recurso literário de efeito sugestivo. 
ocorre agora, por me parecer menos rural que "comer a dois carrilhos", ou outra, semelhante ...

Da figura de estilo pontual, M. Carvalho expande-se para uma convenção mais ampla: aquela que se veio a designar, já em pleno Renascimento, por "utopia", mas que a Antiguidade, sem lhe dar nome, reproduzia já à saciedade. Estamos, assim, diante de um tópico de raízes fundas e convençōes fortes (152):

E Joel traçou a traços gerais, com gestos amplos, os recortes de uma sociedade outra, que eu não sei bem onde fica, mas deve ser à esquina do reino da Barataria com o Kingdom of Nowhere, frente aos domínios da Cocanha, com a ilha da Utopia à vista, rebrilhante dos ouricalcos da Atlântida. ${ }^{30}$

Foi sobretudo a comédia grega antiga o território que mais fôlego deu à célebre fantasia do 'sem lugar'. Capaz de subir às alturas do céu, de baixar ás sombras do Hades, à procura de um bem perdido ou de uma réstia de paz a opor à crise social, a comédia insistiu no modelo com estratégias que, em traços largos, M. Carvalho aqui ressuscita. Utopia é sempre uma alteridade, a busca de um outro lugar diferente daquele que se conhece, por vantagem ou defeito. Lugar esse de pura fantasia, o sem lugar, geograficamente identificado por topónimos que a imaginação ou a tradição mítica inspiram (Barataria, Cocanha, Utopia, Atlântida). Miragens de facilidade ou fortuna (Barataria, rebrilhante dos ouricalcos) ornamentam a utopia, construída em fronteiras difusas, mesmo assim aludidas com abundância de pormenores (uma esquina, frente, uma ilha, à vista) ${ }^{31}$. Nesse horizonte, Joel Strosse procu-

30 Um bom exemplo de estratégia semelhante à aqui usada pode ser a descrição que Caronte, o barqueiro do inferno, faz do itinerário infernal, em Aristófanes, Rãs 185-187: "Quem quer ir para o Eterno Repouso dos males e dos negócios? Quem quer ir para a planície do Esquecimento, para a Terra Onde o Diabo Perdeu a Cartola, para os Cerbérios, para o Raio que o Parta, ou para o Ténaro?” Aqui se misturam topónimos relacionados com a geografia mítica do Hades (o Letes, rio do Esquecimento, ou o Ténaro, um promontório da Lacónia, que marcava a entrada do inferno), gracejos sobre realidades tradicionais no mundo dos mortos (caso do cão Cérbero, o guardião da entrada do palácio de Plutão, que passa a dar nome a um clã ou tribo), e finalmente sobre expressôes que designam, na linguagem comum do grego antigo, fórmulas de não lugar ou maldição (o lugar onde se tosquia o burro, ou ir aos corvos).

31 Sobre a tradição antiga da utopia e algumas das suas mais famosas realizaçóes, vide Melero Bellido, A. (2001), "La utopia cómica o los límites de la democracia", Cuadernos de 
ra, como é de regra, um refúgio ideal, "uma nova sociedade em que ninguém tivesse necessidade de recorrer a paraísos artificiais, em ... em que ... em que", suspensão que abre espaço ao infinito da imaginação humana.

Em contraste com o colorido das figuras de estilo ou o convencional dos eternos episódios da ficção, pode considerar-se o despojamento inábil e elementar do uso da mais neutra das palavras, "coisa" (33):

Reparem bem: coisas - mais tarde, se tiver tempo, falarei sobre a legitimidade da utilizaçáo do substantivo coisa em literatura e jornalismo. Não foi o Bernardim a escrever: "ua cousa cuidava eu / causa de outras muitas cousas ...?".

E mesmo esta palavra, em toda a sua vulgaridade quase agressiva, representa um material informe; moldado por um verdadeiro artista das letras, ou por um descontraído jornalista, o resultado que se produz será indiscutivelmente diverso.

Sem ser decorativo, mas de enorme importância para o tom geral do texto, principalmente para a relação entre o narrador e as personagens, é o uso da pessoa verbal em português, ponto sensível em que a língua condiciona a convivência humana e se converte em elemento sociológico essencial (20):

O licenciado Joel Strosse dificilmente suportava que, fora de uma leve intimidade, um desconhecido o tratasse por você. Você é estrebaria, sete fardos por dia ...

A partir desta sensibilidade do seu protagonista, M. Carvalho enceta a discussão sobre a questão delicada das fórmulas de tratamento na Língua Portuguesa, levada ao exagero de responsável por "duelos e mortes". Como questão a que se quer dar antiguidade na experiência nacional, um recuo ao séc. XIX traz à memória um duelo ocorrido em pleno Chiado, o coração da Lisboa do tempo, causado pela sobranceria fidalga de alguém que brindou outro com um "Vossa Mercê". Transpor o diálogo para época recuada traz ao texto o tom do antigo e revela como, também neste particular, a língua evoluiu impiedosamente. Mas o que permanece é o peso da convenção social e o desentendimento do interlocutor, que se sente visado

Literatura Griega y Latina 3: 7-25; Silva, M. F. (2007), "A porta na comédia de Aristófanes: uma entrada para a utopia", in Ensaios sobre Aristófanes. Lisboa, Cotovia: 257-274; Silva, M. F. (2009), Utopias e distopias. Coimbra, Imprensa da Universidade. 
pela displicência da fórmula. Strosse, agora em pleno séc. xx, tempo que já não é de duelos, não tinha sequer fibra para se arriscar em golpes violentos; mas mais do que condiçóes para tais rasgos de ameaça,

não se encontrava bastantemente apetrechado de independência material e social para enfrentar o seu chefe directo.(20)

Estatuto económico e social, hierarquia, eis o que condiciona sem apelo as subtis nuances do modo de tratamento e incomoda o visado. Do seu interlocutor, o desconhecimento da fórmula correcta revela ignorância, ou pior, uma insolência primária e injustificada ("que ele não se encontrava ao corrente da pragmática do Português. Ou, dito por outras palavras, (...) que o outro era um casca-grossa um tanto ajavardado, simbólico de ruins tempos").

Mais hábil do que o "casca-grossa" director de serviço, a Eduarda Galvão, no assédio que fez do Jorge Matos, seu antigo professor de Francês, de quem deseja auxílio na traduçáo e aconchego num abraço, domina por completo as subtilezas do tratamento. Em escala ascendente, cumpre todas as etapas da abordagem (80):

Atentos como estais, já reparastes que Eduarda subrepticiamente já tinha abandonado no trato o "senhor doutor", passando a "doutor", abrindo a progressão para o "você", ou mesmo "o Jorge" e, sabe-se lá, se "tu". A isto se chama em linguagem popular, esperta para as estratégias, "lançar a escada".

Repetições, redundâncias, figuras de estilo, fórmulas de tratamento constituem todo um património, mais ou menos convencional, que se oferece ao potencial criativo, e crítico, do autor.

\section{A escrita teatral}

À meditação sobre a escrita do romance, M. Carvalho sobrepóe, por intermédio do seu Jorge Matos, professor do ensino secundário, sabedor em francês, "o autor secreto de um montáo de peças de teatro inéditas" (45), uma abordagem da escrita teatral. Não se trata apenas de sublinhar contrastes de género, implícitos neste jogo de texto e sub-texto; trata-se também de considerar o destino de dois géneros a que o universo cultu- 
ral português conferiu distinto aplauso, popular o romance, tantas vezes simplesmente inédito o teatro. É assim que a produção teatral se esgota em sólidas pilhas de papel sobre anónimos sofás, "três ou quatro palmos de verticalidade discutível estratificando catorze peças de teatro" (47).

O estranho divórcio entre a escrita e a cena tem na sua origem - ocorrência dificilmente explicável - o pouco apelo ou tradição de que o teatro goza entre nós. Como tantos outros autores dramáticos, Jorge Matos não era espectador do mesmo (48):

Não por insensibilidade, mas por um motivo absolutamente fútil e irrisório: achava as salas muito desconfortáveis e detestava as peças em que os actores se metiam com o público e não deixavam um sujeito estar sossegado a fruir o seu serão.

As razões são, de facto, "fúteis e irrisórias": a primeira, o desconforto das salas, que é também a inadequação ao espectáculo, a distância, a frieza, que o poder da cena não logra romper. As tentativas de aproximação que os actores ensaiam num esforço para, quebrada a ilusão cénica, envolverem o público - tradiçáo que mais uma vez ascende a pelo menos vinte e cinco séculos de produção teatral, com origem na antiga Grécia, extensão já, ela mesma, de velhas práticas populares - fracassam também; num outro momento e em diferente contexto sabem a artifício, a profissionalismo, não são genuínas, criando reservas, em vez de adesão, no espectador (48):

A repulsa tornou-se ferozmente enfática quando, certa noite, uma personagem saiu do estrado e lhe afagou a barba, enquanto ia declamando solenidades.

É gritante o desajuste entre o que se torna num gesto de intimidade gratuito se concomitante com palavras solenes, inacessíveis, distantes (num risco semelhante ao que o teatro grego correu, ao misturar efeitos trágicos com outros cómicos). Na sua natureza paradoxal, esta parece a combinação ocasional e impensada de tradiçóes conflituosas, a grandiosidade ficcional da cena e a proximidade popular com o auditório. Há, para esse conflito desagradável, que alertar os técnicos (48):

E esta nota fica como motivo de reflexão para encenadores e actores dados ao improviso, e às gestualidades expansionistas, os quais devem 
encarar com muita reserva esta tentaçáo de incomodar quem se disponibiliza nas plateias e tem direito à paz de alma, para não dizer ao conforto.

Não fica sem remoque, na recomendação, o espectador, do outro lado da "parede de vidro" que o separa da cena. Ao uso despropositado da interacção, ele responde com a passividade, refugiado numa frieza e num conforto inertes, o que o torna o espectador indesejável, incapaz de uma verdadeira apate ${ }^{32}$. Nessa falta de interpenetraçáo reside o fracasso do nosso teatro, que de 'observação' - presente na etimologia da palavra 'teatro', como sua marca genética - o reduz a um mutilador objecto de leitura. Epicentro de todo o processo, como espectador em fuga, leitor devoto e criador incansável de peças de teatro, Jorge Matos acumulava os traços essenciais do retrato (48):

Lia as peças, sofria-as, decorava monólogos, sonhava com espectáculos cívicos em que comungassem o mistério, o logos e a polis.

Ou seja, sonhava com um regresso às origens, em que o teatro era de facto um fenómeno aglutinador, de intervenção social, mobilizador dos cidadãos em torno de uma cultura, com uma missão didáctica a cumprir; numa palavra, com o verdadeiro theatron da polis grega de que o espectador solitário, despegado da cena, enfastiado pela mediocridade da proposta se tornou a completa negação.

Mas se crítico e avesso, como espectador, à opçáo decadente do moderno teatro português, o Jorge Matos não soube, como dramaturgo, livrar-se da onda avassaladora que fez dele mais um autor condenado ao pó das prateleiras, pertença do "quarto e do sofá". Os defeitos que o deixavam insensível como espectador contaminaram o seu próprio ensaio de composição. O diagnóstico do fracasso parece fácil de obter: perfeccionismo exagerado, com a consequente falta de autenticidade, dimensão excessiva, falta de operacionalidade cénica, eis o que o padrão corrente denuncia (49):

32 Apate, 'engano ou ilusão', era a palavra que a antiga crítica literária grega usou para a capacidade que uma peça tem de atingir e de influenciar o público. Usada por Górgias no Encómio de Helena 8 e no Fr. B 23 (Plutarco, Moralia 348c), é vulgar em Platão, mas estranhamente ausente da Poética. Contudo um conceito próximo parece aflorar em 1460a 13, $1461 b 11$. 
Aquelas peças que se iam acumulando, algumas bem volumosas, quais delas escritas alucinadamente em noite de insónia, quais delas ponderadas e acrescentadas e alteradas penosamente no decorrer dos anos, estavam ali ...

E pareciam incapazes de se arrancar da inércia e do anonimato, projecção da própria impotência do seu autor. Mas qual a razão de tamanha inoperância? Porquê uma desistência tâo precoce e conformada, que sempre lhes valeu o medo de subirem à cena, afinal o seu primeiro objectivo? "Timidez, medo do inêxito?" A verdade é que, na sua resignação, espelhavam o fosso que separa o gelo da teoria do calor envolvente da prática (49):

Enquanto as peças de teatro dormitassem naquele sofá, era a renovaçáo da dramaturgia portuguesa que estava em potência; uma vez que fossem devassadas, interpretadas, representadas e abominadas, representariam mais uma prova da nossa inépcia para a dramaturgia.

Em resumo, está dentro do espírito dramatúrgico português, no seu sentido mais genérico, a propensão para o demasiado intelectual, em prejuízo do verdadeiramente teatral; numa palavra, potenciais autores de peças para a prateleira esquecida das bibliotecas ou táo somente para o sofá doméstico de qualquer cidadão.

Mas olhemos com mais atenção - valendo-nos da indiscrição que o romance nos faculta desvendando-nos os segredos do Jorge Matos - para alguns dos traços concretos dessa produção de sabor bem português. Primeiro, os temas preferidos quais são? Os históricos compõem um sector bem conhecido. Das catorze que se empilhavam no sofá do Jorge Matos, duas eram históricas (47). E por históricas se pode entender como referentes a um passado distante. Nelas está implicada a necessidade de mergulhar numa outra realidade, de pesquisar detalhes do quotidiano oculto pelo tempo, de transplantar o destinatário, por força de vários estímulos, para o contexto de séculos que não o seu (87):

Ele sabia o bastante sobre ceitis, porque tivera de estudar numismática medieval para uma peça de teatro histórica sobre a questáo da Beltraneja e implicaçóes sociopolíticas correlativas.

Mas histórica é também a abordagem de acontecimentos mais próximos, que saltam das páginas dos jornais para a virtualidade da ficção (49): 
Preparava-se para (...) lançar o terceiro acto de uma teatrada sobre um médico bósnio que o seu próprio filho (de mãe sérvia) sequestra para tratar de um companheiro ferido, tencionando começar com "lembras-te, filho de quando os castanheiros estavam em flor e tu vinhas correndo, de calçóes, gritando ...” Tenso, tenso e comovente ...

À sugestáo discreta de um conflito conhecido da modernidade europeia mistura-se, em flagrante contraste, a reduçáo estreita de tensóes familiares em tempo de guerra. Nada a que uma humanização da tragédia antiga não nos tivesse habituado, já no séc. v a. C., sobretudo pela mão de Eurípides com os seus oikeia pragmata, 'assuntos domésticos' (Aristófanes, Rãs 959). Mas Jorge Matos não é, claro está, um Eurípides! O triângulo familiar, prometedor de um choque de geraçôes, de culturas ou de sentimentos desfecha num convencionalismo frustrante, expresso por memórias artificiais de um passado onde a pujança da natureza esbarra com os vulgares calçóes de um qualquer garoto em fuga. Tudo muito previsível, batido, mas sobretudo vazio de tensão e de talento ...

É ainda do quotidiano social, já não dos grandes conflitos históricos, mas das crises que delapidam a realidade colectiva, que surgem outras fontes de inspiração; talvez porque mal dimensionadas ou restritas na sua formulação, elas póem à prova a fraca imaginação de espíritos sem talento, incapazes de arrancar de uma lista de tópicos uma intriga profunda e coesa (112):

Surpreendido em casa, indefeso, a matraquear a segunda página, ainda de rubricas, de uma outra peça, versando sobre as condiçôes sociais da toxicodependência, Jorge lá abriu a porta ...

Por fim, num afunilar redutor e decadente da perspectiva criadora, vem o aproveitamento de desaguisados pessoais, de rixas domésticas, de divergências conjugais vividas ao telefone, a simples e mera convenção de uma retórica que dá pelo nome de "gritaria ex-conjugal" (197), como fonte de inspiração dramatúrgica:

E no meio de faíscas agressivas, queimadoras, que ressaltavam das recordaçóes, ia-se insinuando em Jorge a tentação de aproveitar o diálogo para a sua última peça de teatro, tal a complexidade da humanal natureza pensante ... 
Do tema se parte para um segundo requisito, o de encontrar para ele o agente mais apropriado, a personagem mais conveniente. E aí a dificuldade recrudesce, o sofrimento refina, num esforço do autor para conferir ao seu actor gestos e palavras adequados. Facilmente a escassez de talento se refugia no artificioso e teatral (53):

Jorge por essa altura sofria, concentrado sobre uma personagem que se interpunha entre dois grupos de guerrilheiros, bradando: "Parem, que razão têm para me matar a mim?", para apontar, depois, o dedo acusador à esquerda e à direita altas: "Que razão têm para se matar assim?” As palavras pareceram-lhe redundantes.

Principalmente os momentos chave, os que abrem ou fecham a acçáo e querem deixar lastro no espectador, são os que exorbitam em convencionalismos e tendem a um espalhafato vazio (74-75):

Mal acabara de atirar os restos de comida para o lixo e imaginava já a última frase da peça, com o pai bósnio a soluçar junto à campa do filho baleado, exclamando: "Nunca mais!" para fazer cair o pano, quando a campainha da porta retiniu ...

Com a instigação de um gesto rotineiro, tendo por Castália um balde do lixo, Jorge abstrai-se no que lhe parece um fim condigno, romântico, patético, expresso em palavras sem sentido, para uma peça também ela fracassada e tremendamente flácida. A que associou outras hipóteses, em dimensóes de mobilizaçáo diversas, ora focadas numa cena divorciada do seu público, logo num público separado da cena, ou, por fim, num modelo globalizante (75):

Talvez fosse melhor a sua personagem rematar com um grito: "O culpado sou eu!" Ou apontando para a plateia: "Os culpados sois vós"” $\mathrm{Ou}$, mesmo, num grande gesto circular: "Os culpados somos todos nós!”

Outras componentes, se não tão extremas, são mesmo assim cruciais. Da velha tradição provêm os longos monólogos, prova de fogo para qualquer actor, desafio à atenção do público - sobretudo o mais susceptível ao visual e avesso ao auditivo -, mas instrumento de expressão de sentimentalidades ou arma de reflexấo dos conceitos sustentadores da intriga, 
como o discurso político em tempo de guerra. Se mal sucedidos, são fonte garantida de um enorme aborrecimento (67):

E logo na manhã seguinte, quando ele pensava inserir na peça sobre a Croácia um atribulado monólogo de doze minutos, muito estruturado, proclamando a renúncia aos canhóes!...

Ou então as metáforas, um instrumento de linguagem mais difuso, remissão disseminada no texto, a apontar para um ponto de referência, no caso obediente ao próprio título (172):

... preferiu recorrer à metáfora do alpinista, que aliás era toda a simbólica da sua última peça de teatro, que se chamava, precisamente, $\mathrm{Na}$ Montanha.

Atenta aos modelos convencionais, conhecedora dos recursos consagrados, a medíocre dramaturgia portuguesa é o resultado de um transplante rotineiro, impessoal, esgotado de efeitos, incapaz de insuflar ânimo novo em fibras ressequidas pelo tempo e pelo uso.

\section{A escrita jornalística}

A experiência, como jornalista, da Eduarda Galvão é o ponto de partida para a caricatura bem sucedida de alguns aspectos da produçáo periodística, de jornais e revistas. Primeiro, os jornais comparecem em Era bom como expressão de uma sociedade de imprensa livre, os tais pasquins "desinibidos", que nem por isso souberam consolidar uma verdadeira informação, séria, consistente, fundamentada. Refugiam-se, isso sim, no pequeno escândalo, na inesgotável corrupção, nos meandros imperscrutáveis da justiça que, como é do domínio público, a nada conduzem (13). Depois de envolvidos em intermináveis e inúteis discussôes produzidas pela grande corrupção, remetem o assunto ao silêncio, já gulosos de novo escândalo promissor de vendas de sucesso. O que num momento alimentou pilhas de papel e rios de tinta remeteu-se, com o tempo, a um total olvido, pontualmente quebrado com "algum remoque raivoso numa coluna de jornal" (15). De registar é a popularidade fácil que adere ao chamamento de títulos vazios ou de fórmulas feitas nas letras gordas ou em grandes frases de fecho, como se neles submergisse a nulidade do conteúdo (18-19): 
... e ter escrito para um jornal popular um artigo célebre intitulado "A mão invisível actua com pés de lã”, finalizado com um bramido muito festejado pela originalidade: "Laissez faire! Laissez passer!"

Mais promissora ainda de paródia é a revista, que M. Carvalho hierarquiza, por países de origem e concomitantes preferências culturais, por públicos alvo, no que parecem os condicionalismos mais restritivos. Afinal não é a imprensa a educar a sociedade, mas esta a impor-lhe exigências, preferências controladas por uma autoridade última: audiências e proventos de vendas.

A imprensa francesa identifica-se pela revista politica, o artigo de fundo, a teoria revolucionária que defende (42):

Joel Strosse tinha agarrado numa revista francesa, Ça ira!, e procurava concentrar-se num artigo intitulado "La gauche post-moderne, une déconstruction en marche?"

Registemos, em primeiro lugar, a determinação do título encontrado para a revista, a apostar num paradigma de apelo revolucionário, Ça ira!, fácil, directo, dirigido a um público determinado. Intenção que o título atribuído ao artigo - La gauche post-moderne, une déconstruction en marche? - não apoia. $\mathrm{O}$ que o título geral tem de informativo e estimulante no seu tom exclamativo, tem o do artigo de ambíguo, de polémico, de possivelmente prolixo, avesso a qualquer objectividade ${ }^{33}$. A um leitor comum, um qualquer Joel Strosse, a sensaboria repisada do assunto, dos conceitos, da linguagem, não lhe permite ultrapassar o primeiro parágrafo, "com aquela chatíssima revista francesa na mão, sem andar nem desandar do sempre mesmo prolixo artigo" (43, 68). Independentemente do número, a Ça ira! prossegue invariavelmente na mesma opção, identificadora de uma imagem comercial (150):

Instalado no escritório, munido de tesoura, ele recortou um artigo da Ça ira!, cujo tema era "adaptação da esquerda consequente às vicissitudes do Mundo moderno".

Incentivada por tempos de revolução e mudança, a imprensa portuguesa, à sua medida, deu sinais de interesse equivalente. Aos acontecimentos

33 Sobre o efeito da linguagem jornalística na sociedade contemporânea - "o cliché é o grande veículo de transporte em comum do pensamento moderno, da comunicação medíocre" - vide Jourdan 1996: 51-52. 
próximos, não foi estranha a tendência para a imitação do que, fora do país, se ia produzindo. Em pasquins anónimos, de província, deu-se largas a um ataque político, de feição extremista e polémica, num estilo adiposo de imagens e metáforas (164), protegido pela couraça de um pseudónimo:

Esse gajo, que depois do 25 de Abril andou a escrever artigos reaccionaríssimos para o boletim paroquial de Fafe, em que chamava à revolução "o touro vermelho" e designava o Álvaro Cunhal por "o demónio branco das estepes?" Até tinha uma frase que ficou célebre: "esses senhores da esquerdaria precisam mas é dumas nalgadas nas abas da consciência" ...

O gajo usava um pseudónimo, O Vingador, ou coisa assim (cf. 176).

Referência da mesma imprensa francesa é o Paris Match (63), numa perspectiva que já não é a da polémica política mas a de uma informaçáo de grande espectro, a pender para o imediato e sensacional, atirado a uma jornalista inicianda como modelo a seguir. Na pele do leitor comum, a Eduarda Galvão desconhece o texto, para se deixar prender pelo acessório, "os bonecos" e os atractivos superficiais da grafia. Um scaphandreur a legendar uma fotografia, para que, no português, não encontrou versão - "escafandrista", "escafundista", "escrafandista" -, seduziu-a pelo exótico do $p h$. E lembrou ao autor a perda, etimológica e exótica, das aspiradas no Português:

Roubaram-nos o phósphoro, a pharmácia, o diáphano, o aphorismo ... Bem assim, o y e o th. Bonito que jazia o myrtho, dolente, ao pé de restos de colunas, em florestas sombrias, cheias de húmus e cogumelos, por onde esvoaçavam divindades, nada aparelhado com o mirto que se vende nas praças, sob gritarias, ao lado de rabanetes e raminhos de salsa ...

Milagre de uma simples aspiraçáo ou $y$ grego, capaz de transformar um mundo remoto, misterioso, divino até, na mais vulgar e rasteira contemporaneidade. Sem o saber, Eduarda 'comprou' esse fascínio de que a Paris Match continua a fazer um trunfo.

Por seu lado, a imprensa espanhola cristalizou nas revistas de VIPs "revistas pernósticas dos vizinhos ibéricos" -, focando-se na imagem de gente distinta, de nome sonante, sempre ocupada em lustrosas e inúteis reuniōes sociais (29): 
... folheando uma propalada revista espanhola, escrita em castelhano, que trata de condes, financeiros, toureiros e mafiosos e de cujo nome não quero recordar-me.

Atenção particular merece a "imprensa feminina", a atrair o empenho calculista dos editores, certos de uma venda segura. Estáo dela arredados os artigos de fundo, com missão social ou educativa, em favor de matérias superficiais, ligeiras, animadas de fotos. A Elle é, do modelo, um paradigma. Em atitude de relaxe e de inércia, em tempo de lazer, Cremilde não "lê", "folheia" a Elle, seduzida por uma informação de discutível utilidade ou pertinência (43-44), veiculada não por uma autoridade, mas por um "alguém" anónimo:

Vem aqui que as varizes não têm cura. A operaçáo pode aliviar um bocado, mas cura é que não há. É um médico que diz. Traz a fotografia e tudo.

Foi nestes sacrossantos modelos que a Eduarda encontrou inspiração para as versóes nacionais que ela mesma, num crescendo profissional, replicou. E M. Carvalho elabora o retrato irónico de uma jornalista criada nas redacçóes, nos modelos importados, penosamente destituída da mais elementar cultura e insensível à estética da língua. A sua primeira experiência na profissão foi na "Modelar (hábil contracção de Moda+Ode+Lar)", título por demais expressivo do fôlego temático e do público destinatário do projecto. Com o desmembramento de uma legenda artificiosa recorda-se o primeiro traço identificativo de uma revista, o título, e o potencial que lhe é próprio, de, em poucas palavras, estabelecer uma proposta, um estilo, um público, um mercado. Inspirado por temas da televisão generalista, o primeiro artigo que a Eduarda se propôs produzir foi sobre o naufrágio do Titanic, claramente arredado dos tópicos da Modelar, moda, ode, lar. Para jovens em busca de afirmação, o tema proposto parece reunir todas as credenciais mais promissoras (55):

É apaixonante, apelativo, dramático, há sobreviventes, implicaçôes religiosas, e, sobretudo, imenso material publicado que se pode plagiar à vontade.

Para além do sensacionalismo, sem compromissos ou riscos sociais porque remissivo para matéria antiga, o naufrágio do Titanic beneficiava ainda da falta de contra prova; e mais do que isso, era matéria requentada, onde 
toda a escassez de talento encontrava refúgio seguro. Ligeireza, ignorância e falta de imaginação, eis o que parece caracterizar o 'tipo' do profissional jornalístico. Não admira portanto as reservas da edição. Mas não se pense que pelas melhores razóes. Afinal o que levantou objecçôes foram "umas complicaçōes de ortografia", e principalmente o desajuste óbvio do assunto em revista feminina, como se o seu valor efectivo fosse critério arredado. A censura não deixava de ter algum fundamento, tidas em conta a frase de abertura, tâo pouco de moda, ode ou lar, tâo pouco de revistas femininas e finalmente tão própria de coisa nenhuma, simplesmente "redundante, burocrática, primária" (56): "Em primeiro lugar temos que considerar que ..." . Gerou-se a confusão na Modelar, entre a aquisiçáo novata, a experiência de trinta anos de jornalismo na censora - estudiosa atenta dos modelos consagrados no jornalismo para a mulher, a Crónica Feminina e a Maria -, e o chefe - e árbitro da contenda -, um antigo negociante de frutas que do assunto nada sabia. Mesmo assim, com um talento inato para a arbitragem de questóes difíceis, o chefe produziu a solução de compromisso: "As Mulheres e o Titanic" ou "O Titanic e as Mulheres" como título salvador, mantidos cortes e correcçóes. Solução salomónica para a boa ordem da editora, ainda que conflituosa para a pertinência do artigo: Titanic e as Mulheres num desencontro flagrante, num vazio irremediável, salvo apenas pela promessa de algum patético. Recordada do sucesso com a Modelar, uma futura mudança para a Reflex viria a abrir nova oportunidade ao naufrágio do Titanic. No que parece já uma sofisticação do usado material, a uma jornalista com algum traquejo a exigência pede outro contorno (171):

Tinha a propor-lhe um trabalho sobre o Titanic, nos aspectos sociais e culturais, bem entendido, trajos, ementas, luxos, etc. Já pensara num título: "O último baile a bordo ..."

Muito promissor agora, o eterno assunto moldava-se melhor à medida do mesmo público. Sem que 'mulheres' tivesse de figurar no título, como um destinatário confesso, a mençáo do baile, associada a trajos, ementas e luxos, fazia com que um naufrágio, assunto mais próprio para "uma revista de musculação" (56), se convertesse em festa de alta sociedade. E aí sim, a imaginação feminina encontraria condimentos da sua preferência.

À mesma galeria editorial da Modelar pertenciam outras pérolas, As Delícias de Satã, O Construtor Civil, Horoscopias, Poupar e Ganhar, Gatinhas em Brasa, títulos unidos pela ambiçáo modesta, pela inutilidade vulgar, mas divergentes no público alvo. $\mathrm{O}$ tom é agora outro, sexo, di- 
nheiro, negócios, a procurarem sensibilidades masculinas. Para satisfazer as necessidades editoriais da Modelar, à equipa de redactoras acresciam outras especialidades, "a colega que redigia os horóscopos e o correio sentimental" e o inevitável fotógrafo (56), para satisfazer o aparato visual que este tipo de literatura jornalística tende a incluir.

Hábil e dotada para a carreira que escolhera, vinda da boutique de um centro comercial com passagem pela caixa de um supermercado (54), Eduarda fez, na Modelar, uma progressão meteórica, que lhe valeu as coroas desejadas. $\mathrm{Na}$ hierarquia da imprensa jornalística, viu o seu nome registado no Expresso, escassos dois meses de tirocínio passados, ainda que com modéstia de espaço (57): "O seu nome veio citado no Expresso, numa pequena local intitulada "Como é isto possivel, meu Deus!". Sobre um título que afinal transparecia a ambiguidade de uma censura, reluzia o brilho de uma qualquer mençáo no Expresso. Logo na sua própria revista os sucessos e as promoçóes se somaram, com ganhos de espaço e diversidade de temas (57); "passou a fazer um novo correio sentimental, O cordão das Emoçóes, e a assinar uma rubrica, Vá descobrindo o seu corpo, ao mesmo tempo que os seus artigos de fundo se coadunavam também melhor com a escola a que a Modelar obedecia, ditada pelos triunfos irrecusáveis da Maria, "que são guia e farol da imprensa". A autora do naufrágio do Titanic, credora de uma oportunidade devida a um talento em potência, pisava terreno firme, consciente das regras precisas do seu contexto profissional.

Ao triângulo formado pelo criador, obra criada, destinatário, falta ainda a palavra ao último, e não despiciendo elemento; se falho de adesão, está posto em causa o equilíbrio gerador de sucesso. A voz do leitor chegou, no caso da Eduarda Galvão, por mão de uma leitora, cuja credencial suprema era a fidelidade à rubrica Cordão das Emoçóes (58). De sua autoria, enviou à Modelar um livro de sonetos, com o toque consentâneo à rubrica de que era leitora assídua, “'Olhando-te, meu amor, um acaso se anuncia”, e por aí fora com rima em ia”. Foi a oportunidade inesperada de a Eduarda se assumir como 'crítica literária', propriamente a coroação de uma carreira. Sobre a oferta redigiu uma nota de censura, pelo retrógrado do modelo poético, e remeteu a autora censurada para a leitura de "Alberto Hélder", o mais longe que podia ir a sua cultura de ouvido. Colhida na Universidade, não da vida, mas da noite - a dos bares e boîtes -, a sua cultura impôs-se a um público de ignorantes entusiastas, seduzidos pela cor gritante de um vocabulário intelectual, onde náo faltavam "blasé, interface, intertextualidade, frontispício, new age, paralaxe, 
pórtico" (58). Mas o certo é que, em homenagem à sua ousadia, se tornou objecto de ofertas constantes de outros títulos, e se pôde dar ao luxo de olhar por cima do ombro os colegas de ofício.

Ganho o sucesso e credenciais de experiência, a transferência para outra revista, a Reflex, uma inovação periodística "que já ia quase no número zero" (60), abriu-lhe as portas à intervenção numa outra rubrica, bem à medida da nova Eduarda, aquela por que era responsável o departamento de Sociedade \& Cultura. Foi diante de uma placa promissora - "Reflex, o Mundo num Relance" -, que nova porta se franqueou à sua ambição. Como tantas outras revistas da Modernidade, a Reflex iniciou-se com pompa e circunstância, "em cerimónia lustrosa e frequentadíssima” (63), que teve por cenário o Palácio de Queluz. Houve banda de música, fardas medievais, discursos, do accionista canadiano e do director indigitado português. $\mathrm{Na}$ linguagem estropiada do primeiro e firme do segundo, foi lançado um voto de sucesso e a profecia da inovação, a promessa de que se tratava de "uma pedrada no charco da informação em Portugal". Em redor, levantou-se o coro reprovador da concorrência, que funcionou sobretudo de publicidade bem vinda. Cumprido o lançamento, veio o plano, accionista e director unânimes na política redactorial a seguir (64):

E resolveram utilizar uma fórmula expedita, impregnada de ecletismo, na composiçáo da redacção: de um lado, uns veteranos empedernidos de andanças em jornais e em protestes cívicos, algo sabedores do prontuário ortográfico; do outro, uma caterva de moços, a que eles chamavam "a passarada", mais virados para as facilidades da vida moderna e da ortografia minimalista.

Diversidade de geraçóes, com a concomitante componente escolar e cultural diversa, sensibilidades distintas na escolha dos materiais e no estilo da redacção, garantiram variedade à informação e amplitude ao leitor visado. Bastou o número zero para testemunhar a pertinência da opção (64):

Ao lado do sisudo artigo de fundo, versando a premência da ética na vida política, aparecia a local brejeira muito "social" com especificações amaricadas e perfidiazinhas do género: "Ai, a Necas ia tão composta no baile dos Vanzeleres... Mas aquele cheiro de after-shave era de origem ou pegado?" 
Desta vez, não se trata de visar públicos femininos ou masculinos, mas um universo indiferenciado, onde a evolução do próprio modelo jornalístico fazia da Reflex um monumento ao anacronismo e à anarquia. Do texto político à crítica social mais brejeira e de mau tom, todos os gostos estavam contemplados, num português mais escorreito ou mais "minimalista".

$\mathrm{Na}$ corrida vertiginosa da inovação, também a Reflex, que vimos nascer com galas de novidade sobre a geração que a Modelar representava, se viu vencida por um outro marco de uma edição mais vanguardista. A queda chegou com a incapacidade de concorrer com a Uau!, uma revista nova vaga "que dedica, no máximo, três linhas a cada notícia, sete aos artigos temáticos e dez ao editorial" (212). Na anulação do interesse, pertinência ou simples configuração dos assuntos, o novo trunfo traduz-se em brevidade, o laconismo que uma geração aprendeu na linguagem dos mails ou das SMS. Com o fluir profissional da Eduarda Galvão, o leitor percorre também um processo evolutivo no critério de revista de grande divulgação. A tendência é para integrar, sob um mesmo título que se quer vistoso, uma produção mesclada, dirigida a um leitor indiferenciado, sem preocupaçóes de utilidade pública. A rendição às preferências do leitor medíocre converteu-se na principal motivação.

Antes de deixarmos a linguagem jornalística, demos ainda espaço a um breve comentário ao que nela são, na sua índole própria, matérias de excelência: a entrevista e a reportagem.

Para a entrevista, o primeiro grande desafio na passagem da Eduarda pelo Departamento Sociedade \& Cultura da Reflex, valeu o modelo celebrado do Paris Match (64-67). E desta vez a inspiraçáo não se ficou pela leitura, foi mais longe; utilizou a réplica, repetiu o padrão, "plagiou" o motivo. A aventura do escafandrista parisiense, o francês Bertrand l’Église, que deu notícia em Paris, foi repetida em Lisboa, em exclusivo para a Reflex. A origem da personagem era modesta, simplesmente a de um funcionário despedido da Renault, imagem de incapacidade e frustração. Que o náo desanimou, antes o incentivou ao golpe popular, a rondar o expediente barato. De um tiro de catapulta que o lançou num voo sobre Paris, ou da aventura de risco numa jaula de leóes do Zoo de Vincennes, o nosso homem acabou escafandrista no Sena, como iniciação à prometida travessia "de todos os rios das principais cidades da Europa". Tanto bastou para o celebrizar no país e no estrangeiro e para atrair a imprensa. Assim se cria o eco fácil da popularidade e do sucesso. Eis o momento para a Reflex, aproveitando o mote, candidatar o Tejo a um segundo momento de celebridade. 
Fotógrafos e operadores de câmara prepararam-se para dar ao episódio o brilho jornalístico merecido. Não sem que o escafandrista, minimamente informado da realidade portuguesa, náo tivesse pensado associar, à imagem, a palavra, e ao seu gesto o lustro das letras. Foi aí que se lembrou de fazer "publicar um álbum com o título Sobolos rios ..., assim mesmo, em português antigo, que dava mais mistério" (65). Junto à Torre de Belém, o cenário escolhido, dava-se uma lição de jornalismo frustrado. $\mathrm{O}$ assunto do mergulho, já de si modesto - sob as penas do sensacionalismo -, fracassava, desde logo pelo pressuposto errado da dimensão do rio, avaliado pela medida do país. Faltava vencer outra barreira, a da língua, que separava o entrevistado da jornalista e do leitor. "Ignorância" seria o título, para todo um episódio de nonsense, mobilizador de um público desqualificado.

Como recurso salvador, a Eduarda, destacada para o efeito, valeu-se do antigo professor de Francês. E teve de reconhecer, perante ele, humildemente, que idiotices do género são tarefas a que se sujeita "a pardalada", os tais jornalistas em início de carreira (72). O resultado esteve ao nível do motivo, o engenho não foi além de um consabido "Aimez-vous rester au Portugal?", a que a resposta "Mais bien sûr je resterais là toute ma vie dès que ...", de tão esperada, não levantaria dificuldades de compreensão $(73,86$, 89). À exuberância de qualquer aventura, a linguagem da entrevista acode com a versão estafada das perguntas e respostas convencionais, transmitida pela tradição profissional, de onde o verdadeiro saber e criatividade estáo ausentes. E prosseguiria com tolices sobre o gosto da aventura que ninguém "dotado de mediano bom senso se daria ao trabalho de ler" (86).

Apesar da mediocridade, a nova jornalista triunfou, exactamente por corresponder às exigências gerais, da produçáo e do consumidor. Coberta de êxitos, a Eduarda foi incumbida de uma outra entrevista, desta vez com responsabilidade: a de questionar Agustina Bessa Luís, nessa altura muito em voga (118). Como preparação, a jornalista ficou-se pelas primeiras páginas da Sibila, lidas já no comboio. E foi com preconceitos infundados na mente - "esperava encontrar uma senhora de meia-idade, de cabelo platinado, num apartamento de duas assoalhadas, rodeada de gatos, com begónias no peitoril das janelas e versos manuscritos emoldurados" - e ideias ligeiras sobre a produção da entrevista que afoitamente se lançou na aventura. A pergunta com que a abordou era de catálogo: "depois de A Sibila, tenciona regressar à escrita? E, se sim, porquê?" (144). E por aqui se ficou, recebendo da escritora uma informação paciente dos rudimentos da sua bibliografia. Foi de novo com a ajuda de Jorge, que do nada surgiu a entrevista escrita, sem a intervenção da interessada, num modelo falsificado 
sobre outras entrevistas com Agustina, testemunhadas por uma colecção de recortes cuidadosamente guardados (170-171). Só mesmo à altura da entrevista feita por um jovem jornalista a um outro escritor; num rasgo verdadeiramente trimalquiónico, em hora de má disposição, o entrevistado debitou, à ignorância do outro, uma mistura anacrónica de episódios e agentes da História (145). Informaçôes essas passadas escrupulosamente a escrito pelo jornalista, compuseram um artigo que fez desabar a Reflex, e a carreira de uma jovem promessa! Risco esse a que a Eduarda se não sujeitava, escudando-se na generosidade de um velho professor arrancado das memórias da juventude. A caricatura do modelo 'entrevista' observa as diversas etapas conducentes ao fracasso: a escolha leviana do motivo, a escassez de formação do jornalista, a pouca exigência do público, sobreviventes à luz de uma preferência pelo sensacionalismo gratuito.

À entrevista acrescente-se a reportagem. Em comum, ambas partilham o mesmo objectivo de facilidade, de exterior sonoro, e um critério ligeiro de selecção explicável por um paradigma canónico (99):

Se um cão morder um bispo, não há notícia, mas se for o bispo a morder o cão, já há.

No momento em que, o que náo passava de um lema teórico, se tornou realidade, o frenesi que se apoderou da redacção ilustrou os interesses vazios da notícia. Multiplicaram-se os depoimentos (100), um sargento da GNR de serviço debitou a fraseologia convencional na circunstância (109): "O caso ("a ocorrência") era da competência dos tribunais, mas não destituída de gravidade” e o dono do cão sustentou que “"ele há coisas nunca vistas" .... $\mathrm{Na}$ sua brevidade, as fórmulas servem para mostrar diferentes estilos, o da GNR e o do mero cidadáo provinciano, que um acontecimento inaudito, mas de alcance modesto, lança para a ribalta. Mais hábil do que os colegas de ofício, foi a Eduarda quem conseguiu o desejado depoimento da figura central, o próprio bispo; com o autoritarismo vulgar na profissão, investiu com a mais tonta das perguntas, ainda que à altura das circunstâncias (111); "Entấo a perna do câo, sabe a quê?" Ao que o bispo respondeu, rendido à sedução da popularidade, com pormenores biográficos, de um passado remoto, num contexto de província e de uma rotina secular (112). A inutilidade dos assuntos, em desequilíbrio com o empolamento da mensagem, as fórmulas feitas, a dimensão da imagem, a repetição insistente, são os sustentáculos de um jornalismo pobre, pouco profissional, socialmente inútil, mas à medida de um colectivo pouco exigente. 


\section{Outras linguagens}

Uma última referência é devida a 'outras linguagens' que perpassam o mosaico de estilos em Era bom. Comecemos por códigos pesados e formais, conectados com certas formas de cultura, elitistas e selectivas na sua índole, mas enfadonhas para o leitor comum. São deles exemplo, "um recital de poesia hexamétrica em baixo-latim" (13) com que uma Fundação de cultura brinda, por mecenato, uma plateia restrita. Com maior amplitude, uma tese académica alarga o modelo. Destinada sobretudo ao pó das prateleiras, depois de lida por um destinatário escasso - "ainda não foi publicada", 19 -, esta criação cultural pende para assuntos circunscritos, minúsculos e por demais aprofundados, a ponto de caírem na insignificância - "As Disposições das Alminhas nas Encruzilhadas do Alto da Beira" como tema de Antropologia Analítica -, no âmbito de saberes a que o homem comum reage com assombro. Mas, subjacente à excepcionalidade do tema, está um estilo medíocre, um português paradoxalmente impreciso e falho de rigor - "... há-de interessar pouco que um licenciado escreva perjorativo em vez de pejorativo, árbito em lugar de árbitro, ou orquesta por orquestra”. E, no entanto, a mediocridade deste tipo de produtos é sancionada por júris internacionais, numa manifesta indiferença que parece não ter fronteiras, pela má qualidade. Estranhamente, o nível da linguagem dos trabalhos académicos parece pautar-se por uma ignorância palmar e por uma completa e tolerada falta da rigor.

Se sairmos do território estreito da cultura académica para o campo sem limites da sociedade comum, dois padróes merecem comentário; o da linguagem burocrática e o da publicidade; em campos muito distintos, ambas construíram o seu próprio protocolo.

A burocracia vive de fórmulas, de clichés repetitivos, de que a imaginação está arredada e onde a criatividade é proibida. Ao funcionário inconformado com o espartilho da profissão não está permitido mais do que 'traduzir' fórmula por fórmula, num empenho insano, mas votado ao fracasso, de criar estilo; e, por estranho paradoxo, Vaz Alves, na pele do burocrata por excelência, assumiu consigo o compromisso de náo repetir vocabulário de ofício para ofício, armado de um dicionário de sinónimos (24). Ao serviço de uma Fundação, que entendia como versão de uma empresa, redimiu-se de clichés vulgares e procurou criar os seus próprios (22):

Aos destinatários do giro da empresa preferia chamar "o cliente difuso", designação que lhe parecia preferível à de "cliente global", 
configurando os "alvos" da "oferta de produtos". Nessa conformidade (ele dizia "como tal"), o primeiro requisito que se exigia era que os colaboradores (eufemismo para "empregados") fossem capazes de "implementar" em primeiro lugar a eficácia, em segundo, a eficácia e em terceiro, a eficácia”.

Feita da força do nome e do seu atributo, a variação formular de uma empresa criou o seu padrão próprio para o triângulo fornecedor, produto $\mathrm{e}$ cliente, num leque estreito, convencional, a breve trecho desgastado, onde a imaginação escasseia como mola da tão propalada eficácia. Mesmo se limitada, a linguagem burocrática conhece nuances e campos semânticos. O burocrata, se transplantado de serviço dentro da mesma instituição, do andar administrativo para o da biblioteca, depara-se com a necessidade de mudar de estilo, e a prosa profissional regista a troca. Aí, a simples consulta de despachos em arquivo à espera de remessa confronta-o com uma realidade ainda mais formal e codificada (25):

Em resposta à prezada carta de $V^{a}$ Ex a datada de ... do corrente, cumpre-nos informar que o seu projecto denominado "Biblioteca Elementar Básica", se bem que interessante não consta actualmente das prioridades da Fundação.

Acusamos recebida a amável oferta de $\mathrm{V}^{\mathrm{a}} \mathrm{Ex}$ a que penhoradamente agradecemos, ou verificando com pesar que $\mathrm{V}^{\mathrm{a}} \mathrm{Ex}{ }^{\mathrm{a}}$ ainda náo devolveu ...

Do que, no piso da administração, parecia ainda revestido de "encanto e de império", não restava, na biblioteca, mais do que "o sombrio, descritivo e monótono" ofício. O nome e o qualificativo cediam espaço à concorrência do advérbio, "actualmente, penhoradamente, com pesar", todos eles confinados a um circuito fechado de propostas de projectos, ofertas e aquisiçôes. Aí o "cliente difuso ou global" cristaliza no tratamento de Va Ex a e o "colaborador ou empregado" ofusca-se no anonimato de um plural majestático, "cumpre-nos", "acusamos", "agradecemos".

Por flagrante contraste, a linguagem publicitária, solta de quaisquer limites que não sejam os da concretização de uma finalidade - vender -, usa da imaginação, da criação de clichés, que ela mesma, sem freio, altera e produz. Lacónica no estilo, a publicidade vive do som, do inconformismo das palavras, do artifício da rima, do tom proverbial, como incentivos à memorização involuntária. Assim, nas campanhas de produtos alimentí- 
cios, "Farofeiras no bolso / o melhor almoço" (47), "Fubá, o melhor que há!" (67); ou então o recurso ao irreal para promover o concreto, como por exemplo um automóvel (118): "Um automóvel como os outros? Não, este carro não consome combustivel. Consome fantasia, etc., atmosfera irreal, não sei quê, etc.". Ainda que oca de sentido, a publicidade vibra em sons, exclamaçôes, interrogaçóes retóricas, aproveitando as virtualidades da língua talvez tanto quanto o atractivo da imagem. A banalidade que a linguagem literária não tolera garante ao estilo mediático uma difusão inegável.

Tal como começamos, acabaremos com palavras de Zagajewski (2003, En la belleza ajena, trad. espanhola, Valência: 38), sobre a relação polémica que os vários níveis da criação literária ou linguística estabelecem entre si, e com outras criações artísticas:

O que mais ameaça os poetas não são as violentas arremetidas dos propagandistas puritanos, nem os ataques saídos da pena dos seus irmãos - romancistas (...). O mais perigoso é a indiferença, a ilimitada indiferença dos passageiros dos comboios suburbanos e dos fanáticos da televisão. O pior é quando ninguém escreve panfletos contra a poesia. 


\section{Bibliografia Geral}


(Página deixada propositadamente em branco) 


\section{Ediçôes de Mário de Carvalho}

(21990), Contos da sétima esfera. Lisboa, Caminho.

(1991), Quatrocentos mil sestércios. Lisboa, Caminho.

(71991), Casos do beco das sardinheiras, Lisboa, Caminho.

(31993), A Paixão do Conde de Fróis. Lisboa, Caminho.

(1996), Os Alferes. Lisboa, Caminho.

( $\left.{ }^{3} 1996\right)$, O livro grande de Tebas, Navio e Mariana. Lisboa, Caminho.

(1997), Um deus passeando pela brisa da tarde, Lisboa, Caminho.

$\left({ }^{3} 1997\right)$, Fabulário. Lisboa, Caminho.

(52003), Era bom se trocássemos umas ideias sobre o assunto. Lisboa, Caminho.

(32004), Fantasia para dois Coronéis e uma Piscina. Lisboa, Caminho.

('2006), A inaudita guerra da Avenida Gago Coutinho. Lisboa, Caminho.

(2008), A sala magenta. Lisboa. Caminho.

(2010), A Arte de Morrer Longe. Lisboa, Caminho.

\section{Estudos}

Adorno, T. W. ('1983), "Posição do narrador no romance contemporâneo". In: Benjamin, Honkheimer, Adorno, Habermas. Trad. port. José L. Grünnewald et alii. São Paulo, Abril Cultural: 269-273.

Albaladejo, T. (1986), Teoría de los mundos posibiles y macroestructura narrativa. Alicante, Universidade de Alicante.

Albaladejo, T. (1992), Semántica de la narración: la ficción realista. Madrid, Taurus.

Albérès, R. M. (1972), Métamorphoses du roman. Paris, Albin Michel.

Almeida, J. F. (1997), Bíblia Sagrada. Rio de Janeiro, Fecomex (Ed. Revisada e corrigida).

Alves, C. C. (2010) "Vestígios do trágico em Mário de Carvalho”. Navegaçôes 3. 1: 53-58.

Anacleto, M. T. (1996), “(Sub)versions du "cliché” romanesque au XVII siècle: le "roman bourgeois" de Furetière”, Confluências 14: 97-109.

Angelini, P. R. K. (2011) "Recensão de Carvalho, M. A arte de morrer longe. Lisboa, Caminho, 2010. 128p.”. Navegaçōes 4. 1: 131-133.

Arnaut, A. P. (2001), "Donas e donzelas n'a Demanda do Santo Graal”, Santa Barbara Portuguese Studies. Califórnia, n. 5: 29-71. 
Aristófanes (21989), A Paz. Tradução de Silva. M. F. Coimbra, Instituto Nacional de Investigação Científica.

Aristófanes (2006), As Aves. Tradução de Silva, M. F. Lisboa, Edições 70.

Aristóteles (1986), Poética. Tradução de E. Sousa. Lisboa, Fundação Gulbenkian.

Arnaut, A. P. (2002), Post-Modernismo no romance português contemporâneo. Fios de Ariadnemáscaras de Proteu. Coimbra, Almedina.

Assis, A. K. T. (2008), Arquimedes, o centro de gravidade e a lei da alavanca. Montreal, Apeiron Montral.

Auerbach, E (1976), Mimesis (A representação da realidade na literatura ocidental). São Paulo, Perspetiva [1 $1^{\text {a }}$ ed., 1946].

Aurélio, Marco (1971), Pensamentos. Versão de João Maia. Lisboa, Editorial Verbo.

Bakhtine, M. (1970), La Poétique de Dostoievsky. Paris, Éd. du Seuil.

Bakhtine, M. (1981), Dialogic imagination: four essays. Austin, University of Texas Press.

Bakthine, M. (1981), Problemas da poética de Dostoievski. Trad. port. Paulo Bezerra. Rio de Janeiro, Ed. Forense-Universitária.

Benjamin, W. (1985), "Sobre o conceito de História. Tradução de Sérgio Paulo Rouanet”. In: Obras escolhidas. Magia e técnica, arte e política. São Paulo, Editora Brasiliense: 222-232.

Bessière, J. (2010), Le roman contemporain ou la problemacité du monde. Paris, PUF.

Beye, C. R. (1964), "Homeric battle narrative and catalogues", Harvard Studies in Classical Philology 68: 345-373.

Bergson, H. (2001), O riso: ensaio sobre a significação da comicidade. Trad. port. Ivone C. Benedetti. São Paulo, Martins Fontes.

Bhabha, H. K. (1998), O local da cultura. Belo Horizonte, Editora UFMG.

Bianchet, S. B. (2004), Petrônio. Satyricon. Edição bilíngüe. Belo Horizonte, Crisálida.

Bougnoux, D. (1991), "Le principe d'identification”. In Personnage et Histoire Littéraire. Toulouse, Presses Universitaires du Mirail: 187-195.

Brandão, J. L. (2001), A poética do Hipocentauro: Literatura, sociedade e discurso ficcional em Luciano de Samósata. Belo Horizonte, Ed. UFMG.

Brasete, M. F. (2003), “A crítica às mulheres no fr. 7 de Semónides de Amorgos”. In: Mora, C. M. (ed.), Sátira, Paródia e Caricatura: da Antiguidade aos nossos dias. Aveiro, Universidade de Aveiro: 39-56.

Brauner, E. F. (2009), “" Era bom que trocássemos umas ideias sobre o assunto”: ironia de um narrador e discussão do romance", Revista Electrónica de critica e teoria de literaturas. Dossiê: o romance português e o mundo contemporâneo 5. 2. Porto Alegre: 1-9.

Buescu, H. (1995), A Lua, a Literatura e o Mundo. Lisboa, Cosmos. 
Buescu, M. L. C. (1979), Aspectos da herança clássica na cultura portuguesa. Lisboa, Instituto de Cultura Portuguesa.

Camôes, L. (1979), Os Lusíadas. Prefácio de Hernâni Cidade. São Paulo, Abril Cultural.

Carcopino, J. (1993), La vida cotidiana en Roma en el apogeo del imperio, trad. esp. Madrid, Ediciones Temas de Hoy.

Cardoso Bernardes, J. A. (1988), O Bucolismo Português. A égloga do Renascimento e do maneirismo. Coimbra, Livraria Almedina.

Carvalho, M., (2003), "Mário de Carvalho: crónica do aturdimento". JL - Jornal de Letras, Artes e Ideias 864, 12/11: 12.

Ceia, C. (2007), A Construção do romance (Ensaios de literatura comparada no campo dos estudos anglo-portugueses). Coimbra, Almedina.

Chevalier, J., Gheerbrant, A. (1994), Dicionário dos Símbolos, trad. port., Lisboa, Editorial Teorema.

Colaço, J. (1995), “Mário de Carvalho”, Biblos. Enciclopédia verbo, I, s.u.

Compagnon, A. (2001), O demônio da teoria: Literatura e senso comum. Belo Horizonte, Editora UFMG.

Constâncio, N. (2007), Ruinas e incertezas em "Um Deus passeando pela brisa da tarde”, de Mário de Carvalho. Lisboa, Edições Colibri.

Costa, L. S. (1995), “Era Bom que Trocássemos Umas Ideias Sobre O Assunto, de Mário de Carvalho. A Arquitectura, A Violência”. In: Público/Leituras, 11 de Novembro:10.

Cotrim, J. P. (1996), Entrevista a Mário de Carvalho: "Alguma coisa me perturba”. Ler/Livros e Leitores 34: 45.

Cotrim, J.P. (1996), "Mário de Carvalho. O Mistério da Literatura”, entrevista ao autor. LER 34, Primavera.

Cristóbal, V. (1992), "Búsqueda de campo, hastío de ciudad. Pasión antigua y contemporánea”. In: Guzmán, A. et alii (ed.), Aspectos modernos de la Antigüedad y su aprovechamiento didáctico. Madrid, Ediciones Clásicas: 131-143.

Davison, M. (1976), "The thematic use of ekphrasis in the ancient novel”, in Erotica antiqua. Acta of the International Conference on the Ancient Novel. Bangor, ICAN: 32-33.

Devereux, G. (1975), Dreams in Greek tragedy. Oxford, Basil Blackwell.

Dijksterhuis, E. J. (1987), Archimedes. Translated by C. Dikshoorn. Princeton University Press.

Diogo, A. A. L. (1997), "Exórdio". In: Biblos- Enciclopédia Verbo das Literaturas de Lingua Portuguesa. Lisboa, São Paulo, Verbo.

D’Onofrio, S. (1978), Poema e Narrativa: estruturas. São Paulo, Duas Cidades. 
Duncan, T.S. (1935), “The deus ex machina in Greek Tragedy”. Philological Quarterly 14: $126-141$.

Dunn, F. M. (1985), Euripidian Endings: a Study of the Choral Exit, the Action, the Concluding Prophecy and the Deus ex Machina. Yale University: 111-167.

Eco, U. (1979), Leitura do Texto Literário. Lector in Fabula. Trad. Mário Brito. Lisboa, Presença.

Entrevista com Mário de Carvalho http://www.homemmag.pt/pt/index.php/arte-e-literatura/arquivo-arte-literatura/87-luisa-costa-gomes-entrevista-mario-de-carvalho

Ernout, A. ( $\left.{ }^{11} 1993\right)$, Pétrone. Le Satyricon. Paris, Les Belles Lettres.

Ernout A, Meillet, A. ( $\left.{ }^{4} 1967\right)$, Dictionnaire etymologique de la langue latine: histoire des mots. Paris, Librairie C. Klincksieck.

Errandonea, I. (1954), Diccionario del mundo clásico. Barcelona, Editorial Labor.

Eschilo ( $\left.{ }^{4} 2000\right)$ I sette contro Tebe. Con testo a fronte. Introd. Umberto Albini. Trad. Ezio Savino. Milano, Garzanti Editore.

Feijóo, B. (1998), Um Não Sei Quê. Lisboa, Vega [1746].

Ferreira, C. (2003), “Mário de Carvalho. A arte de bem iludir o leitor”. In: Rodapé: 45-51.

Ferreira, P. S. (1999), “A paródia e as suas implicações didácticas”. In: Torrão, J. M. N. (ed.), III Colóquio Clássico - Actas. Aveiro, Universidade de Aveiro: 113-137.

Ferreira, P. S. (2000), Os elementos paródicos no Satyricon de Petrónio e o seu significado. Lisboa, Colibri.

Ferreira, P. S. (2003), “Paródia ou paródias?”. In: Mora, C. M. (ed.), Sátira, Paródia e caricatura: da Antiguidade aos nossos dias. Aveiro, Universidade de Aveiro: 279-300.

Fialho, M. C. (1992), Luz e trevas no teatro de Sófocles. Coimbra, Instituto Nacional de Investigação Científica.

Figueiredo, M. N. (2006), "Com humana crueldade se tece um conto. A propósito de Homenagem ao Papagaio Verde”. In: Santos, G. (ed.) Jorge de Sena: Ressonâncias e Cinqüenta Poemas. Rio de Janeiro, 7Letras.

Fowler, D. P. ((1991), "Narrate and describe: the problem of ecphrasis", Journal of Rhetorical Studies 81: 25-35.

Frow, J. (1986), “Spectacle Binding: On Character”. Poetics Today 7. 2: 227-250.

Gaffiot, F. (1934), Dictionnarie Illustré Latin-Français. Paris, Librairie Hachette.

Garrett, A. (1973), Viagens na minha Terra. Rio de Janeiro, Editora Três.

Genette, G. (1972), Figures III. Paris, Ed. du Seuil.

Gennete, G. (1997), L'Cuvre de l'Art. La Relation Esthétique, II. Paris, Ed. du Seuil.

Genette, G. (2004), Métalepse. Paris, Ed. du Seuil.

Gomes da Torre, M. (1992), “Acerca da tradução da metáfora”. Linguas e Literaturas 9: 209-226. 
Grimal, P. (s/d), Dicionário de Mitologia Grega e Romana. Lisboa.

Guillén, J. (1977), Vrbs Roma - vida e costumbres de los romanos, vol. I: La vida privada. Salamanca, Ediciones Sígueme.

Guthrie, W. K. C. (1976), Les Sophistes. Paris, Payot.

Halliwell, S. (1968), Aristotle's Poetics. Chicago and London.

Hamon, P. (1976), “O que é a descrição?”. In: Seixo, M. A. (ed.), Categorias da narrativa. Lisboa, Arcádia: 61-83.

Hardwick, L. (2003), Reception Studies. Greece and Rome. New Surveys in the Classics. Oxford, Oxford University Press. [recensão do livro por Martin M. Winkler, in Bryan Mawr Classical Review 2004].

Heródoto. (2002), Histórias. Livro I. Tradução de Ferreira, J. R., Silva, M. F. Lisboa, Ediçóes 70. Heródoto (1997), Histórias. Livro III. Tradução de Silva, M. F., Abranches, C. Lisboa, Ediçóes 70. Heródoto (2000), Abranches, C., Histórias. Livro IV. Tradução de Silva, M. F., Abranches, Lisboa, Edições 70.

Homero (2003), Odisseia. Tradução de Frederico Lourenço. Lisboa, Livros Cotovia.

Homero (2005), Ilíada. Tradução de Frederico Lourenço. Lisboa, Livros Cotovia.

Hoorn, J. F., and Konijn, E. A. (2003), "Perceiving and experiencing fictional characters: An integrative account”. Japanese Psychological Research 45. 4: 250-268.

Horácio (1975), Arte Poética. Tradução de R. M. R. Fernandes. Lisboa, Clássica Editora.

Hutcheon, L. (1977), “Modes et formes du narcisisme littéraire”. Poétique 29: 90-106.

Hutcheon, L. (1984), Narcissistic Narrative. The Metafictional Paradox. New York and London, Methuen.

Hutcheon, L. (1985), A Theory of Parody. The Teachings of Twentieth Century Art Forms. New York \& London, Methuen; (1989), Uma teoria da paródia, trad. port. Lisboa, Ediçóes 70.

Hutcheon, L. (1988), A poetics of Postmodernism. History, Theory, Fiction. New York/London, Routledge; (1991), Poética do Pós-Modernismo. Trad. Ricardo Cruz. Rio de Janeiro, Imago.

Hutcheon, L. (2000), Teoria e Política da Ironia. Trad. port. Julio Jeha. Belo Horizonte, Editora UFMG.

Immerwahr, H. R. (1966), Form and thought in Herodotus. University of North Carolina.

Izaac, H. J. ( ${ }^{3} 1969$, 1973), Martial. Épigrammes, I-II. Paris, Les Belles Lettres.

Jauss, H. R. (1986), Experiencia y Hermeneutica Literaria. Ensayos en el campo de la experiencia estétca. Madrid, Taurus, [1977].

Jenny, L. (1979), "A estratégia da forma”, Poétique. Revista de teoria e análise literárias. Trad. port. Clara C. Rocha. Coimbra, Almedina: 5- 49. 
Jerome, K. J. , “Three men on the Brummel'. In: http://www.gutenberg.org/catalog/world/ readfilefk_files $=2061881$

Jourdan, P. (1996), "Paul Valéry chasseur de perroquets", Confluências 14: 51-59.

Júdice, N. (1997), Viagem por um século de Literatura Portuguesa. Lisboa, Relógio d'Água.

Julien, Y. (1998), Aule-Gelle. Les nuits attiques, IV. Paris, Les Belles Lettres.

Jurado, F. G. (1999), "Apuntes para una historia prohibida de la literatura latina en el siglo XX: La voz de los lectores no académicos”. In: Morán, M. C. A.; Iglesias Montiel, R. M. (eds.), Contemporaneidad de los clásicos en el umbral deI tercer milenio. Actas deI Congreso Internacional Contemporaneidad de los clásicos: La tradición greco-latina ante el siglo XXI. La Habana, Universidad de Murcia: 77-85.

Kerferd, G. B. (2003), O movimento sofista. Trad. port. Margarida Oliva. São Paulo, Ediçôes Loyola.

Kirk, D. M. (1960), The digression, its use in prose fiction from the Greek romance through the eighteenth century. Stanford University.

Kristeva, J. (1974ª), Introdução à semanálise. São Paulo, Perspectiva.

Kuester, M. (1992), Framing Truths - Parodic Structures in Contemporary English-Canadian Historical Novels. Toronto/London, Toronto University Press.

Lausberg, H. (1963), Elementos de retórica literária. Trad. port. Raul M. Rosado Fernandes, Lisboa, Gulbenkian.

Leão, D. F. (1996), “Trimalquião: a humanitas de um novo-rico”. Humanitas 48: 161-182.

Leão, D. F. (1997), “Trimalquião à luz dos Caracteres de Teofrasto”. Humanitas 49: 147-167.

Leão, D. F. (1998), As Ironias da Fortuna. Sátira e Moralidade no Satyricon de Petrónio. Lisboa, Colibri.

Leão, D. F. (2004), “Zoilo e Trimalquião, duas variaçôes sobre o tema do novo-rico”. Humanitas 56: 191-208.

Leão, D. F. (2004a), “O Satyricon de Petrónio e a crise dos paradigmas tradicionais”. In: Nascimento, A. (ed.), Antiguidade Clássica: Que fazer com este património?. Lisboa, Centro de Estudos Clássicos: 233-242.

Leão, D. F. (2005), Petrónio. Satyricon. Lisboa, Cotovia.

Lepaludier, L (2002), Métatextualité et métafiction. Théorie et analyses, Presses Universitaires de Rennes, CRILA.

Levi, P. (1988), É isto um homem? Rio de Janeiro, Rocco.

Lévy, E. (1983), "Le théâtre et le rêve: le rêve dans le théâtre d'Eschyle", in Zehnacker, H. (ed.), Théatre et spectacles dans l'Antiquité. Actes du Colloque de Strasbourg. Leiden: 141-168.

Lopes, S. R. (2003), Literatura, Defesa do atrito. Lisboa, Copiart. 
Lourenço, E. ('1982), "Da literatura como interpretação de Portugal”. In O Labirinto da Saudade (Psicanálise Mitica do Destino Português). Lisboa, D. Quixote: 85-126.

Lourenço, F. (2003), Homero. Odisseia. Lisboa, Cotovia.

Luciano (1996), Uma história verídica. Tradução de C. Magueijo. Lisboa, Editorial Inquérito Limitada.

Lukács, G. (1989), Théorie du roman. Paris, Flammarion [1916].

"Na Lusitânia com Mário de Carvalho (História, paródia e ironia em Quatrocentos mil sestércios e Um deus passeando pela brisa da tarde)". In Veredas 5 (2002) 211-224.

Macedo, A. G. (2008), Narrando o pós-moderno: reescritas, revisôes, adaptaçôes. Braga Universidade do Minho.

Machado, J. P. (1995), Dicionário etimológico da Língua Portuguesa. Lisboa, Livros Horizonte.

Malina D. (2002), Breaking the frame: metalepsis and the construction of the subject. Columbus, Ohio State UP.

Margolin, U. (2005), “Character”. In: Herman, D., Jahn M., Ryan, M.-L. (eds.), Routledge Enciclopedia of Narrative Theory. London/New York, Routledge: 54-57.

Marinho, M. F. (1996), "O sentido da história em Mário de Carvalho", Revista da Faculdade de Letras. Linguas e Literaturas: 257-267.

Marinho, M. F. (2010), "À la recheche de l'identité perdue. Essai sur la crise d'identité dans le roman portugais contemporain”. In: Besse, M. G. \& Ralle, M. (eds.), Les Grands Récits: Miroirs Brisés? Paris, Índigo:186-198.

Martin, F. (1987), Les mots latins. Paris, Hachette.

Martins, J. C. O. (2011), "Mário de Carvalho e a reflexão metaficcional sobre o futuro do romance”. Diacrítica. Dossiê Literatura e Religiāo 25/3: 23-44.

Martins, J. C. O. (2011), “Pensar Portugal - ironia, paródia e desencanto: Mário de Cavalho e o retrato melancólico de um país". In: Carvalho da Silva, J. A., Martins, J. C. O., Gonçalves, M. (eds.), Pensar a Literatura no Séc. XXI. Braga, Univ. Católica Portuguesa: 463-478.

Martins, J. C. O. (s.d.), "La barbarie de l'ignorance dans la culture postmoderne et la fiction de Mário de Carvalho". In: De l'Extrême: pratiques du contemporain dans les mondes ibériques et ibéro-américains, Paris, CRIMIC [em publicação].

Martins, M. F. (1983), Sombras e transparências da literature. Lisboa, INCM.

Martins, Maria João (2003), "Mário de Carvalho: crónica de um aturdimento" [entrevista], JL - Jornal de Letras, Artes e Ideias, no 864, 12 novembro, p. 12.

Mead, G. (1990), “The Representation of Fictional Character”. Style 24. 3: 440.

Medeiros, W. (1997), "Do desencanto à alegria: o Satyricon de Petrónio e o Satyricon de Fellini”. Humanitas 49: 169-175. 
Melanda, P. C. O. (2001), Pela mão de Clio. A reescrita da História em Mário de Carvalho. Aveiro. 38. Dissertação de Mestrado em Estudos Portugueses, apresentada à Universidade de Aveiro. Exemplar em CDRom.

Melero Bellido, A. (2001), "La utopia cómica o los límites de la democracia”, Cuadernos de Literatura Griega y Latina 3: 7-25.

Melero Bellido, A. (2004), "La lengua de la utopia". In: López Eire, A., Guerrera, A. R. (Eds.). Registros Lingüísticos en las lenguas clásicas. Salamanca, Ediciones Universidad Salamanca: 149-172.

Mendes, A. M. G. (1999), "Cultura clássica em Um Deus Passeando pela brisa da tarde de Mário de Carvalho”, III Colóquio Clássico - Actas, Aveiro: 347-363.

Mendes, A. M. G. (2005), “Trimalquião, os coronéis e a piscina: retrato impiedoso de um país em crise”. Ágora. Estudos Clássicos em Debate. Aveiro 7: 129-150.

Mendes, J. P. (1997), Construção e Arte das Bucólicas de Virgílio. Coimbra, Almedina.

Mendonça, F. (1997), “A Paixão do Conde Fróis”. Colóquio/Letras 99. Setembro-Outubro.

Mexia, P. (2005), “O Manuel Germano”. Diário de Notícias. Artes, 17 de Junho: http:// dn.sapo.pt/2005/06/17/artes/o_manuel_germano.html

Moisés, M. ('1973), A criação literária: introdução à Problemática da Literatura. São Paulo, Melhoramentos.

Mora, C. M. (2003), “A outra resposta de Tirésias”. In: Mora, C. M. (ed.), Sátira, Paródia e caricatura: da Antiguidade aos nossos dias. Aveiro, Universidade de Aveiro: 7-13.

Morais e Silva, A. (1953), Grande Dicionário da Lingua Portuguesa. Lisboa, Confluência.

Mourão, J. A. (1998), "Posfácio”, a Feijóo, Benito - Um Não Sei Quê. Lisboa, Vega.

Nickel, R. (1999), “Lucian's True Story: impressions of a fancy voyage”, Euphrosyne 27: 249-257.

Niederauer, S. (2008), "Era bom que trocássemos umas ideias sobre o assunto ou $\mathrm{O}$ simulacro da narrativa na pós-modernidade”. Letras de Hoje 43. 4: 83-88.

Oliveira, B. S. (1997), Eurípides. Hipólito. Brasília, Editora UNB.

Onelley, G. B. (2004), “A resistência da nau: cidade na luta pelo poder”. Calíope 12: 33-42.

Otte, G. (1996), "Rememoração e citação em Walter Benjamin". Revista de Estudos de Literatura 4. Belo Horizonte, Centro de Estudos Literários (CEL), Faculdade de Letras da UFMG: 211-223.

Pereira, E. (2003), "Viagens na minha terra: ciladas da representação". Revista do Centro de Estudos Portugueses 23 n. 32: 61-68.

Pereira, S. M. (2008), “Poética dos sonhos e das visōes em estado de vigília - I”, Humanitas 60: 11-28.

Pereira, S. M. (2009), "Poética dos sonhos e das visōes em estado de vigília - II”, Humanitas 61: 5-18.

Perelman, C. O. (1993), O Império Retórico: Retórica e Argumentação. Tradução de Fernando Trindade e Rui Alexandre Grácio. Porto, Ediçóes Asa. 
Perrin-Naffakh. A.-M. (1996), "Le langage cliché: aveu d'usure ou pouvoir d'écho". Confluências 14: 7-14.

Perrone-Moisés, L. (1979), “A intertextualidade crítica”. Poétique. Revista de teoria e análise literárias. Trad. port. Clara C. Rocha. Coimbra, Almedina: 209-230.

Pimentel, C. S. (2001), "O latim nas literaturas portuguesa e francesa: instrumentos, métodos e agentes de ensino”, Ágora, Estudos Clássicos em Debate 3: 183-185.

Piwnik, M.-H. (1998), "Mário de Carvalho: crónica de um desfecho anunciado", Veredas 1, Porto: 317-325.

Piwnik, M.-H. (2004), “De Sienkiewicz a Mário de Carvalho: Duas construções da História”. In: Literatura e História. Actas do Colóquio Internacional, Porto, vol. II: 139-144.

Platão ( $\left.{ }^{12} 2010\right)$, República. Trad. Maria Helena da Rocha Pereira. Lisboa, Fundação Calouste Gulbenkian.

Préchac, F. (1987), Sénèque. Lettres a Lucilius, II. Paris, Les Belles Lettres.

Queirós, E. de (s./d.), Os Maias. Lisboa, Livros do Brasil.

Queirós, E. de (2000), O Crime do Padre Amaro. Ed. crítica de Carlos Reis e M. Rosário Cunha. Lisboa, IN-CM.

Rabaté, E. (1996), "Henri Michaux et le cliché: résistance et fascination”. Confluências 14: 61-75.

Raimond, M. (1989), Le Roman. Paris, Armand Colin.

Reis, C. (1996), "Mário de Carvalho. Incitação ao romance”. Jornal de Letras 28 Agosto: 22-23.

Reis, C. (1997), "Fábula”. In: Biblos-Enciclopédia Verbo das Literaturas de Lingua Portuguesa. Lisboa, São Paulo, Verbo: 462-463.

Reis, C. (2005), História crítica da literatura portuguesa, vol. IX (Do neorrealismo ao postmodernismo). Lisboa, Verbo: 287-318.

Reis, C., Macário Lopes, A. C. (72007), Dicionário de narratologia. Coimbra, Almedina.

Ricoeur, P. (1983), Temps et Récit. T.I. Paris, Ed. du Seuil.

Rio Torto, G. M. (1996), "Linguagem e clichê", Confluências 14: 159-175.

Robilliard, M.-A. (2002), Água em pena de pato de Mário de Carvalho. Um teatro do desencanto. Trad. port. Manuel Ruas. Lisboa, Editorial Caminho.

Rocha Pereira, M. H. (1955), Concepçōes Helénicas de felicidade no além: de Homero a Platão. Coimbra, Maranus.

Rocha Pereira, M. H. (1980), Poesia Grega Arcaica. Coimbra, Instituto de Estudos Clássicos.

Rocha Pereira, M. H. (1984), Estudos de História da Cultura Clássica, vol. II (Cultura Romana). Lisboa, Fundação Calouste Gulbenkian.

Rocha Pereira, M. H. ('1994), Romana - Antologia da Cultura Latina. Coimbra, Universidade de Coimbra. 
Rocha Pereira, M. H. ( $\left.{ }^{10} 2006\right)$, História da Cultura Clássica, I (Cultura Grega). Lisboa, Fundação Calouste Gulbenkian.

Rodrigues, L. G. (2005), “A Radioestesia”. In http://rprecision.logspot.com/2005/06/radiestesia.html Rose, M. A. (1979), Parody and meta-fiction. London, Croom Helm.

Sant'Anna, A. R. ('1985), Parodia, paráfrase \& cia. São Paulo, Ática.

Santos, R. B. (2009), Aspectos da Herança Clássica em Mário de Carvalho. Belo Horizonte, Faculdade de Letras da UFMG, 2009. [versão policopiada].

Saramago, J. (1989), História do Cerco de Lisboa. Lisboa, Caminho.

Saramago, J. (1990), "História e Ficção”. Jornal de Letras, Artes e Ideias, 6 de Março.

Schaeffer, J. M. (1992), L'art de l'àge moderne. L'esthétique et la philosophie de l'art du XVIIIème siècle à nos jours. Paris, Gallimard.

Schmidt, W. (1963), Der Deus Ex Machina bei Euripides. Tübingen University.

Schwartz, J. (1981), Murilo Rubião: A poética do Uroboro. São Paulo, Editora Ática.

Scodel, R. (1999), Credible impossibilities. Conventions and strategies of verisimilitude in Homer and Greek tragedy. University of Michigan Press.

Sedlmayer, S., "Sinais de fogo, aviso de incêndio: ideias estéticas, históricas e literárias em Jorge de Sena e Walter Benjamin”. In: Revista Literatrua e Autoritarismo. Dossiê Walter Benjamin e a Literatura brasileira. Santa Maria, Universidade Federal de Santa Maria/ RS. Disponível em http://w3.ufsm.br/grpesqla/revista/dossie05/art_02.php

Seel, M. (1992), "Le langage de l'art est muet". In: Bouchindhomme, Ch., Rochlitz, R. (eds.), L'art Sans Compas. Redéfinitions de l'Esthétique. Paris, Éd. du Cerf.

Segurado e Campos, J. A. (1991), Cartas a Lucílio, Lisboa, Fundação Calouste Gulbenkian.

Seixo, M. A. (1995), "Mário de Carvalho. Romance, Humanismo e BD”, JL - Jornal de Letras, Artes e Ideias, 12. 4: 24-25.

Sena, J. http://www.letras.ufrj.br/lerjorgedesena/port/antologia/ficcao-e-teatro/texto.php?id=319

Sequeira, M. G. R. (1996), Aproximação a uma Leitura do Risivel em A Paixão do Conde de Fróis. Tese de Mestrado apresentada à Faculdade de Letras da Universidade do Porto (dact.).

Settis, S. (2006), El futuro de lo 'clásico'. Traducción de Andrés Soria Olmedo. Madrid, Abada Editores.

Silva, M. F. (1987), Critica do teatro na comédia antiga. Coimbra, INIC.

Silva, M. F. (2005), Ensaios sobre Euripides. Lisboa, Cotovia.

Silva, M. F. (2007), "A porta na comédia de Aristófanes: uma entrada para a utopia”. In: Ensaios sobre Aristófanes. Lisboa, Cotovia: 257-274. 
Silva, M. F. (2008), "Mensagens, cartas e livros no teatro grego antigo", in Matos, M. C. (ed.), Helénicos. Estudos em homenagem do Prof. Jean-Pierre Vernant (1914-2007). Lisboa, Ediçôes Távola Redonda: 227-260.

Silva, M. F. (2009), Utopias e distopias. Coimbra, Imprensa da Universidade.

Silvestre, O. M. (1998), "Mário de Carvalho: Revolução e Contra-revolução ou um passo atrás e dois à frente”. Colóquio/Letras 147/148: 209-229.

Silvestre, O. e Diogo, A. L. (1998), "Entrevista a Mário de Carvalho", in <http://www. ciberkiosk.pt>, arquivo, $\mathrm{n}^{\circ} 1$ (15 pp.).

Simões, M. J. (2006), “Atrevidas e desbordantes: as personagens em Mário de Carvalho”. In Figuras da Fiç̧ão. Coimbra, Centro de Literatura Portuguesa: 79-92.

Spivak, G. Ch. ('2003), “Can the subaltern speak?” In: Asheroft, B., Griffith, G., Tiffin, H. (eds.), The post-colonial studies reader. New York, Routledge.

Spivak, G. Ch. (1998), "Puede hablar elsujeto subalterno?”. Orbis Tertius 3. 6: 1-44.

Sterne, L. (1860), The Works of Lawrence Sterne. London, Henry Bohn.

Thomasson, A. (2003), "Fictional Characters and Literary Practices". British Journal of Aesthetics 43. 2, April:138-157.

Todorov, T. (1999), O homem desenraizado. Trad. Christina Cabo. Rio de Janeiro, Record.

Torrão, J. M. N. (ed.) (1999), III Colóquio Clássico. Aveiro, Universidade de Aveiro.

Tosi, R. (2000), Dizionario delle sentenze latine e greche. Milano, Biblioteca Universale Rizzoli.

Trindade, L. (2004), “Os excessos de Abril”, História 65: 20-31.

Valente, A. M. (2004), Aristóteles. Poética. Lisboa, Gulbenkian.

Várzeas, M. (2001), Silêncios no teatro de Sófocles, Lisboa, Cosmos.

Villeneuve, F. (1970), Horace. Odes et Epodes, I. Paris, Les Belles Lettres.

Xavier, L. G. (2007), O discurso da ironia. Lisboa, Novo Imbondeiro.

Walton, K. (1990), Mimesis as Make-Believe: On the Foundations of the Representational Arts. Cambridge Mass., Havard University Press.

Waugh, P. (2003), Metafiction. The Theory and Practice of Self-Conscious Fiction. London \& New York, Routledge [1984].

Wesseling, E. (1991), Writing History as a Prophet. Postmodernist Innovations of the Historical Novel. Amsterdam/Philadelphia, John Benjamins.

Wolff, F. (2004), “Quem é bárbaro?”. In: Novaes, A. (ed.), Civilização e Bárbarie. São Paulo, Companhia das Letras: 19-43.

Woods, J. (1974), The Logic of Fiction. Paris, Mouton; (2010), A Mecânica da fiç̧âo. Lisboa: Quetzal. Zagajewski, A. (2003), En la belleza ajena, trad. esp. A. E. Diaz-Pintado Hilario, Valencia, Pre-Textos. 